\title{
Is there an efficient trap or collection method for sampling Anopheles darlingi and other malaria vectors that can describe the essential parameters affecting transmission dynamics as effectively as human landing catches? - A Review
}

\author{
José Bento Pereira Lima ${ }^{1,2,3 /+}$, Maria Goreti Rosa-Freitas ${ }^{4}$, \\ Cynara Melo Rodovalho',2, Fátima Santos ${ }^{5}$, Ricardo Lourenço-de-Oliveira ${ }^{4}$ \\ ${ }^{1}$ Laboratório de Fisiologia e Controle de Artrópodes Vetores ${ }^{4}$ Laboratório de Transmissores de Hematozoários, \\ Instituto Oswaldo Cruz-Fiocruz, Rio de Janeiro, RJ, Brasil 'Laboratório de Entomologia, Instituto de Biologia do Exército, \\ Rio de Janeiro, RJ, Brasil ${ }^{3}$ Fundação de Medicina Tropical Doutor Heitor Vieira Dourado, Manaus, AM, Brasil \\ ${ }^{5}$ Odebrecht Angola - Projectos e Serviços Ltda, Luanda, Angola
}

\begin{abstract}
Distribution, abundance, feeding behaviour, host preference, parity status and human-biting and infection rates are among the medical entomological parameters evaluated when determining the vector capacity of mosquito species. To evaluate these parameters, mosquitoes must be collected using an appropriate method. Malaria is primarily transmitted by anthropophilic and synanthropic anophelines. Thus, collection methods must result in the identification of the anthropophilic species and efficiently evaluate the parameters involved in malaria transmission dynamics. Consequently, human landing catches would be the most appropriate method if not for their inherent risk. The choice of alternative anopheline collection methods, such as traps, must consider their effectiveness in reproducing the efficiency of human attraction. Collection methods lure mosquitoes by using a mixture of olfactory, visual and thermal cues. Here, we reviewed, classified and compared the efficiency of anopheline collection methods, with an emphasis on Neotropical anthropophilic species, especially Anopheles darlingi, in distinct malaria epidemiological conditions in Brazil.
\end{abstract}

Key words: Anopheles darling - malaria - collection methods - traps

History and basics of collecting mosquitoes - The collection of live insects has occupied humans since before historical times. Whether for their beauty or for scientific interest, morphological and natural observations of insects' life cycles have always attracted human curiosity. A small percentage of insects are haematophagous. The recognition of the importance of bloodsucking insects as vectors of parasites occurred only recently in human history. Among the bloodsucking insects, mosquitoes are of major importance for parasite transmission. Mosquitoes are holometabolic insects with four life stages: eggs, larvae, pupae and adults. The majority of mosquito species require blood for egg maturation. Adult females are the bloodsucking stage related to the transmission of parasites and are most easily trapped as they search for blood. Therefore, adult females of mosquito species are the main focus of entomological studies in transmission areas.

Although entomology as a discipline dates to at least 300 BC (as documented in Aristotle's times), it was not

doi: 10.1590/0074-0276140134

Financial support: FIOCRUZ/SVS

+ Corresponding author: jbento@ioc.fiocruz.br

Received 17 April 2014

Accepted 9 July 2014 until the end of the 1800s that mosquitoes were revealed as vectors of parasites, including Culex for bancroftiasis (Manson 1877), Aedes for yellow fever (Finlay 1881) and Anopheles for malaria (Ross 1898, Grassi 1898) (Sanjad 2003). Accompanying these discoveries, the quest for the appropriate collection method for a given mosquito species has been an important pursuit for both academics and control personnel (WHO 1975a, b, 2002, Service 1977, 1993, Beaty \& Marquardt 1996). Academics and technicians have known from the beginning that to understand transmission dynamics, appropriate qualitative and quantitative collection methods had to be developed.

Distribution, abundance, feeding behaviour, host preference, parity status and human-biting and infection rates are among the medical entomological parameters evaluated in any vector species because these factors are essential in the determination of the vectorial competence of natural populations (Garrett-Jones 1964, Massad \& Coutinho 2012). The number of mosquitoes caught can provide an estimate of human-biting activity (Odetoyinbo 1969, Zaim et al. 1986, Lines et al. 1991, Githeko et al. 1994, Davis et al. 1995, Shiff et al. 1995, Costantini et al. 1998b, Mboera et al. 1998, Magbity et al. 2002). Parity status is a proxy of the survival time of adult female mosquitoes and determines whether a parasite has sufficient time to complete its life cycle within the mosquito, thus determining whether the mosquito will serve as an effective vector (Lourenço-de-Oliveira et al. 1989, Gama et al. 2013, Rubio-Palis et al. 2013). 
With regard to other vector-borne human parasites, anopheline mosquitoes that transmit malaria prefer human blood, a trait known as anthropophily. Anthropophilic anophelines live near and benefit from, the human host in a behaviour known as synanthropy. Human malaria is, thus far, associated only with humans and is therefore considered an anthroponosis. In a mosquito population with dozens of anopheline species, the more anthropophilic an anopheline species is, the higher its efficiency in transmitting malaria and, therefore, its importance as a vector. Collection methods take advantage of this anthropophilic preference to lure anopheline females by using humans or human characteristics as attractants.

Egg traps and collection methods for immature anophelines are available (WHO 1975a, Harris et al. 2011). However, the present review is concerned only with collection methods for adult female anophelines that exhibit anthropophilic behaviour.

The various methods of collecting anthropophilic anophelines - As with any other anthropophilic mosquito species, the process of anthropophilic anophelines searching for a blood meal is likely to involve a complex, interconnected cascade of behaviours involving olfactory, visual and thermal cues (de Jong \& Knols 1995, Cork 1996, Clements 1999, Takken \& Knols 1999, Cardé \& Willis 2008, Cardé \& Gibson 2010). Human odours generally act as attractants to anthropophilic anophelines (Knols 1996, Costantini 1996, Costantini et al.
1996, 1998a, Mboera 1999, Murphy et al. 2001). Nonetheless, human breath odour has been shown to be repellent to anophelines (Mboera et al. 1997, Mukabana et al. 2004a). Human skin bacteria are also involved in the composition of human odours (Verhulst et al. 2011).

Environmental, seasonal and circadian variables may also affect the activity and attraction of anthropophilic anophelines and it is likely that all collection methods lure anthropophilic anophelines using a combination of visual, thermal and olfactory cues.

There are many types of traps and collection methods for adult female anophelines. In this review, the terms "anopheline collection methods" and "traps" will be used interchangeably. Anopheline collection methods for anthropophilic species have mainly used humans as the bait or attractant or imitate human-related characteristics in their design. In fact, the human landing catch has been, from the beginning, the most effective collection method for anthropophilic anophelines.

Here, we list and discuss the most recent and most widely used collection methods for anthropophilic anophelines in Latin America. A comprehensive list of mosquito collection methods can be found elsewhere (Service 1993). We also compare the efficiency of a few anthropophilic anopheline methods in the field in Brazil.

Anopheline collection methods - We tentatively classify anopheline collection methods based on their main attractant into four classes: biological, chemical, physical and physical/chemical (Fig. 1).

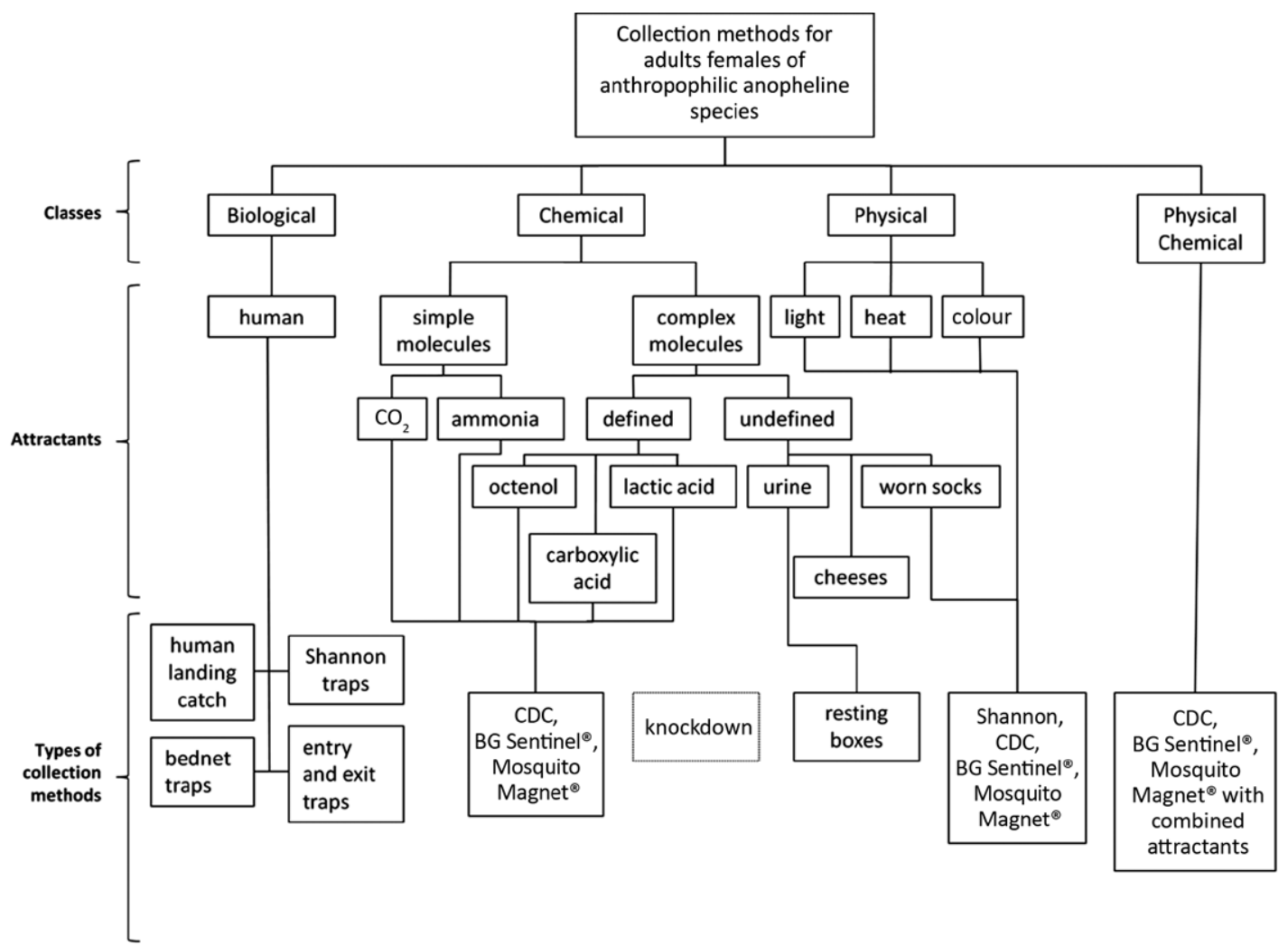

Fig. 1: types of anopheline collection methods for adult females of anthropophilic species. $\mathrm{CO}_{2}$ : carbon dioxide. 
Biological methods for collecting anthropophilic anophelines use whole organisms, such as humans and other animals, as attractants. Chemical collection methods for anthropophilic anophelines utilise chemical attractants. These chemical attractants range from simple molecules [such as carbon dioxide $\left(\mathrm{CO}_{2}\right)$, which resembles human exhalation] to more complex molecules (such as semiochemicals or hormones) or a mixture of simple and complex molecules mimicking scents and products released by the human body (Takken \& Knols 1999). Among the physical attractants, anthropophilic anopheline collection methods can use colour (mimicking hiding or resting places), light (mimicking human domiciles) and heat (mimicking the human body temperature). Physical/chemical anthropophilic anopheline collection methods use characteristics from both methods to enhance the results. Common types of chemical, physical and physical/chemical anthropophilic anopheline collection methods include a suction fan used to aspirate adult specimens, after which they desiccate in bags, adhere to sticky surfaces or are electrocuted when contacting a charged grid.

Biological - Humans - For anthropophilic anophelines, there has been no better or more productive means of collection than the use of a human individual as an attractant (Service 1977, Hii et al. 2000, Santos et al. 2000, WHO 2002, Kweka \& Mahande 2009, Dusfour et al. 2010, Duo-quan et al. 2012). For ethical reasons, the human landing catch method has been strictly limited. Notwithstanding, it remains the most accurate method to determine key entomological parameters and to evaluate control measures that are of paramount importance for vectors of human diseases (Pates \& Curtis 2005, Fornadel et al. 2010). In the human landing catch, a human individual typically sits, exposes his/her legs, waits for anthropophilic anophelines to land and captures them with a manual aspirator, ideally before being bitten.

One of the main disadvantages of the human landing catch is that it is labour intensive and produces variable results due to the individual variation in human attractiveness and skill in mosquito capture (Muirhead-Thomson 1951, Smith 1956, Smart \& Brown 1957, Brouwer 1960, Gilbert et al. 1966, Spencer 1967, Mayer \& James 1969, Carnevale et al. 1978, Port et al. 1980, Curtis et al. 1987, Schreck et al. 1990, Knols et al. 1995, Lindsay et al. 1993, Brady et al. 1997, Mukabana 2002, Mukabana et al. 2002, 2004b, Qiu et al. 2006). In addition, pregnancy can make humans more attractive to anthropophilic anophelines (Lindsay et al. 2000, Ansell et al. 2002, Himeidan et al. 2004). Yields from human landing catches translate directly into human-biting rates, which serve as a basic parameter for the estimation of both the entomologic inoculation rate and the vectorial capacity (MacDonald 1957, Davis et al. 1995, Githeko et al. 1996, Beier et al. 1999, Hay et al. 2000, Robert et al. 2003, Kelly-Hope \& McKenzie 2009, Dusfour et al. 2012, Escovar et al. 2013, Wong et al. 2013).

The human landing catch was previously referred to as "human bait". The change in nomenclature, from human bait to human landing catch, arose from the search for alternative methods. Anopheline collection using hu- mans as attractants has been debated by ethical committees worldwide in the last two decades, mainly because of the potential threat of malaria infection to the mosquito collector. This danger is of particular concern in malaria holoendemic areas or in drug-resistant Plasmodium areas, such as malaria-endemic areas in Africa. Together, these disadvantages have led to ethical dilemmas (Rubio-Palis \& Curtis 1992, Kilama 2010) discussed in institutional review boards and ethical committees that resulted in the restriction and even the banning of the human landing catch as an anopheline collection method, with some such committees going so far as to deem this method an occupational hazard (Mirabello et al. 2008).

Some researchers have attempted to increase the protection for themselves and the personnel engaged in collecting anthropophilic mosquitoes by ameliorating the human landing catch method and placing the person serving as an attractant in a protective tent.

In the quest for an efficient, sensitive and safe collection method for anthropophilic anophelines, there has been a long list of evaluations of methods, including traps, with the aim of finding a method able to evaluate entomological parameters as accurately as the human landing catch that is also cost effective, exposure free and widely deployable (Mirabello et al. 2008), especially in areas of low densities of anthropophilic anophelines (Mathenge et al. 2004, 2005, Mboera 2005, Govella et al. 2009, JBP Lima et al., unpublished observations).

Shannon tents - One of the most efficient collection methods for anophelines is the use of baited traps. Among baited traps, Shannon-type tent traps are widely used and can use a human individual, an animal or light as attractant (Shannon 1939, Service 1977, Dutra et al. 1996, Alencar et al. 2012). Shannon-type tent traps making use of light as the only attractant may show a discrepancy in anthropophilic anopheline yields. Shannontype tent traps making use of light sometimes collect large numbers of anthropophilic anophelines, whereas, in some cases, the yield is low. In our opinion, the large anthropophilic anopheline yields observed for Shannon traps making use of light are likely to be due to the presence of the human collector rather than to the presence of light only. When the human collector leaves the Shannon trap with the light unattended and comes back to collect from time to time, anthropophilic anopheline yields are low. Shannon-type tent traps also show discrepant results for different anopheline species. The results from Shannon-type tent traps may correlate well quantitatively with human landing catch collections when the total number of anopheline species is considered independent of vector density. Qualitatively, however, our experience indicates that Shannon-type traps using animals and/or light attract a great number of non-vector species, such as Anopheles peryassui, Anopheles shannoni and Anopheles matogrossensis (R Lourenço-de-Oliveira, unpublished observations). There are many Shannon-type traps currently in development in the non-commercially available stage, some of which are designed to protect the human individual used as an attractant from bites (Mboera 2005, JBP Lima et al., unpublished observations). 
Anthropophilic anopheline collection methods using Shannon-type tent traps include the traditional Shannon tent (Shannon 1939), the Ifakara trap (Anderson et al. 2000, Govella et al. 2009, 2010, 2011, Sikulu et al. 2009, Okumu et al. 2010b), the Mbita trap (Mathenge et al. 2002, 2004, 2005, Laganier et al. 2003), the Malaise trap (Smith et al. 1965, Malaise 1936, Wallace et al. 1977), the Malayan trap (Colless 1959) and the Furvela trap (Odiere et al. 2007, Govella et al. 2009, Kweka et al. 2009, Stoops et al. 2010). The high survival of anthropophilic anopheline specimens in Shannon tent traps allows for the use of specimens caught for other entomological indices, such as those for the determination of parity, malaria infection rates and insecticide resistance.

Bed net traps - Some Shannon-type tent traps have been adapted for use as bed net traps (Mathenge et al. 2002) and a variety of these bed net traps have been tested in Africa, where malaria vectors are strongly endophilic. Bed net traps are not as efficient as human landing catches (Service 1993, Le Goff et al. 1997), but have been shown to capture anthropophilic anopheline females with comparable parity rates and with sporozoite indices comparable to those obtained in human landing catches (Le Goff et al. 1997). To our knowledge, bed net traps have not been evaluated in Brazil.

Entry and exit traps - Traps placed in the entry or exit apertures of human domiciles are called entry and exit traps, respectively. Windows are typically used as entry and exit traps (WHO 1975a) and were successfully used in monitoring vector density in southern Africa (Mouatcho et al. 2007, Odiere et al. 2007, Govella et al. 2010, 2011), El Salvador (Rachou et al. 1965) and Equatorial Guinea (Sharp et al. 2007). Entry traps are designed to catch anthropophilic anophelines entering domiciles. In Africa, entry traps exploit the tendency of endophilic African malaria vectors to rest and possibly mate in intradomicile areas after blood feeding (Dao et al. 2008). The so-called Lehmann's funnel entry trap is placed at house windows to capture and hold anthropophilic anopheline females entering domiciles (Diabaté et al. 2013). In contrast, exit traps take advantage of the behaviour of anthropophilic female anophelines leaving the domicile at sunrise for egg laying. The main disadvantage of entry/exit traps is that when sampling anophelines escaping from domiciles (Service 1977), the results are positively affected by the presence of insecticides on bed nets or walls, which promote exit (Chareonviriyaphap et al. 1997, Diuk-Wasser et al. 2005, WHO 2005, Muenworn et al. 2006, Mouatcho et al. 2007, Pothikasikorn et al. 2007, Sharp et al. 2007), and are negatively affected by behavioural changes in anthropophilic anopheline populations, such as outdoor resting (Muirhead-Thomson 1960, Smith 1961, Bogh et al. 1998, Quinones et al. 1998, Sumodan et al. 2004, Richards et al. 2006, Chaves et al. 2010), due to the selection pressures of indoor insecticide spraying (Taylor 1975, Chareonviriyaphap et al. 1997, Hemingway et al. 2002, Pates $\&$ Curtis 2005). Moreover, domiciles present entry and exit points in variable quantity and quality; sometimes it is difficult to find a spot that can be used as an entrance or escape route for endophilic mosquitoes (Govella et al. 2011). In fact, the presence of many entry and exit points, sometimes represented by the lack of a door and windows, is a characteristic of the Amazonian domiciles of human populations throughout South America.

Chemical - Several hundred volatile molecules are produced by a human individual (Stoddart 1990, Bernier et al. 2000, Curran et al. 2005, Gallagher et al. 2008). These volatile molecules comprise simple and complex structures and are known as kairomones. Kairomones

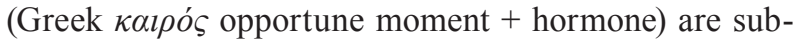
stances opportunistically used as odour cues by predators to locate their prey and by parasites to locate their host. It has been hypothesised that parasitised hosts can emit odour signals to vectors (Braks et al. 1999).

Among kairomones there are simple molecules, such as $\mathrm{CO}_{2}$ (Gillies 1980, Costantini et al. 1996, Mboera et al. 2000b) and ammonia (Meijerink et al. 2001, Njiru et al. 2006), as well as more complex molecules, such as carboxylic fatty acids (Knols et al. 1997, Costantini et al. 2001), oxo-carboxylic acids (Healy \& Copland 2000), ketones (Takken et al. 1997), phenols (Takken et al. 1997, Hallem et al. 2004) and L-lactic acid (Braks et al. 2001). All of these kairomone molecules can be potentially used as attractants in anthropophilic anopheline collection methods (Cork 1996, Healy \& Copland 2000, Meijerink et al. 2001, Jawara et al. 2009).

Simple molecules - From the hundreds of molecules composing the odours produced by humans, only a few human odour molecules have been singly tested as attractants for anthropophilic anophelines and other mosquito species, such as Aedes aegypti (Davis 1984, Healy \& Copland 1995, Geier et al. 1999, Bernier et al. 2000, Braks et al. 2001, 2002, Healy et al. 2002, Smallegange et al. 2005).

$\mathrm{CO}_{2}$ - Among the most common simple molecule used in anopheline collection methods is $\mathrm{CO}_{2}$, which is exhaled by all vertebrates. $\mathrm{CO}_{2}$ was acknowledged as a mosquito attractant in the late 1930s (Van Thiel et al. 1939, Reeves 1953, Mboera \& Takken 1997) and later for both African and American anopheline species (Gillies \& Wilkes 1968, Gillies 1980, Kline et al. 1991, Faye et al. 1992, Service 1993, Healy \& Copland 1995, Costantini et al. 1996, Rubio-Palis 1996, Mboera \& Takken 1997). $\mathrm{CO}_{2}$ from dry ice used in CDC traps increased mosquito catches by $400-500 \%$ (Newhouse et al. 1966). $\mathrm{CO}_{2}$ has been observed to contribute to the attraction of anthropophilic anophelines (Snow 1970, Healy \& Copland 1995, Costantini et al. 1996, Mboera \& Takken 1997). In an anthropophilic anopheline trap, $\mathrm{CO}_{2}$ can be provided in many ways. It can be supplied in pure form via a $\mathrm{CO}_{2}$ cylinder (released at $500 \mathrm{~mL} / \mathrm{min}$ ), formed from dry ice, produced through the catalytic conversion of propane (released at $350 \mathrm{~mL} / \mathrm{min}$ ) or from yeast fermentation (Kline 2002, Oli et al. 2005, Smallegange et al. 2010, Obenauer et al. 2013), including sachet granules made from yeast and sugar (Saitoh et al. 2004, Oli et al. 2005). In addition, yeast growth produces by-products in addition to $\mathrm{CO}_{2}$ (Hazelwood et al. 2008). Some fermentation by-products have been identified as volatile organic 
compounds that are also found in human emanations and may play a role in anthropophilic anopheline attraction in addition to $\mathrm{CO}_{2}$ (Qiu 2005, Smallegange et al. 2005, 2009, Verhulst et al. 2009).

Examples of commercial traps that use the simple chemical molecule $\mathrm{CO}_{2}$ as an attractant and that were tested for collecting anthropophilic anophelines include the CDC trap (Center for Disease Control and Prevention, USA), the BG-Sentinel ${ }^{\circledR}$ trap (BioGents HmGb, Germany) and the Mosquito Magnet ${ }^{\mathbb{} T M}$ trap (Woodstream Corporation, Pennsylvania) (Njiru et al. 2006, Qiu et al. 2007, Schmied et al. 2008). The Mosquito Magnet ${ }^{\circledR}$ trap and its variations is a propane-powered $\mathrm{CO}_{2}$ trap (Kline 2002). In the Mosquito Magnet ${ }^{\mathbb{Q}}$, propane is catalytically converted to produce $\mathrm{CO}_{2}$, heat and water vapour (Kline 1999, Johansen et al. 2003). The Mosquito Magnet ${ }^{\circledR}$ produces a down-flow plume of $\mathrm{CO}_{2}$ through a central pipe and a small fan blows the adult anophelines approaching the trap down into a net cage (Kline 1999). The BGMalaria trap and its variations (Gama et al. 2013) are still in the non-commercial stage. The CDC, BG-Sentinel ${ }^{\mathbb{B}}$ and Mosquito Magnet ${ }^{\circledR}$ also use a fan to produce suction to capture anthropophilic anophelines and other mosquitoes in receptacles, where they can be further analysed. It has long been known that using the CDC trap without its original light, but with alternative attractants, such as $\mathrm{CO}_{2}$, may increase yield (Carestia \& Savage 1967, Takken \& Kline 1989). However, CDC traps using only $\mathrm{CO}_{2}$ as the attractant performed poorly when sampling the anthropophilic Anopheles aquasalis in Suriname (Hiwat et al. 2011a). In contrast, Anopheles darlingi from Suriname was more attracted by $\mathrm{CO}_{2}$ in $\mathrm{BG}$-Sentinel ${ }^{\circledR}$ traps than by a protected human individual sleeping in a hammock nearby (Hiwat et al. 2011b).

Octenol - The molecule 1-octen-3-ol, or octenol, is a common volatile originally found as a derivative of gasses produced in the rumen of cows (Hall et al. 1984), as well as in mushrooms and truffles; octenol gives the odour of Camembert cheese a mushroom note. Octenol has also been found in blue cheeses and in some fruit sources, such as raspberries and orange juice oil, in elder flowers and in Australian prawns and sand-lobsters (Cotton 2014). Octenol is an effective attractant for anthropophilic anophelines and other mosquito species (Kline et al. 1990b, Eiras 2001, Lozovei 2001, Silva 2003). Octenol strips are convenient and can last for up to three-four months depending on storage and weather conditions (Xue et al. 2008). The use of octenol as the only attractant for Neotropical anthropophilic anophelines has not been found in the literature.

Combined simple molecules - Anopheline collection methods using $\mathrm{CO}_{2}$ and other attractants have been largely assessed with results varying from mediocre to successful (Rubio-Palis 1996, Mboera et al. 2000a, Kline 2002, Hiwat et al. 2011b). A mixture of $\mathrm{CO}_{2}$ plus odour in traps enhances anopheline collection results (Costantini et al. 1996, Cooper et al. 2004, Qiu et al. 2007, Hiwat et al. 2011b). The combination of attractants such as $\mathrm{CO}_{2}$ and octenol in CDC light traps greatly enhances the yield of mosquitoes, including anopheline malaria vectors (Rubio-Palis 1996, Xue et al. 2008). Octenol has been used as a single attractant or in combination with other attractants $\left(\mathrm{CO}_{2}\right.$, butanone, L-lactic acid, acetone, butyric acid) for anthropophilic anophelines in many different types of traps (Takken \& Kline 1989, Kline et al. 1990a, Vythilingam et al. 1992, Cork \& Park 1996, Mboera et al. 2000a); it has also been tried for Neotropical anthropophilic anopheline species (Rubio-Palis 1996). $\mathrm{CO}_{2}$ sachets and octenol strips are easy to carry and store and are safe to handle (Xue et al. 2008). In one study, human-specific 7-octenoic acid combined with $\mathrm{CO}_{2}$ attracted a greater number of Anopheles gambiae s.l. (Costantini et al. 2001). The Shannon-Ifakara-type tent trap also uses odours (such as aqueous ammonia, Llactic acid and several other carboxylic acids $+\mathrm{CO}_{2}$ ) to attract anthropophilic anophelines (Okumu et al. 2010b). In one study using Mosquito Magnet ${ }^{\mathbb{}}$ traps, the addition of $\mathrm{CO}_{2}$ to a blend of ammonia + L-lactic acid + 3-methylbutanoic acid used as synthetic odours considerably increased anthropophilic anopheline yields as well as the yields of other mosquito species (Qiu et al. 2007). The BG-Sentinel ${ }^{\circledR}$ trap is compact and easy to transport and uses colour and chemicals as attractants (Geier et al. 2004, Schmied et al. 2008, Bhalala et al. 2010). The BG-Sentinel ${ }^{\circledR}$ trap can use attractants containing ammonia, lactic acid and fatty acids developed to mimic human skin odour to attract anthropophilic anophelines. The effectiveness of the trap can be enhanced when used in combination with $\mathrm{CO}_{2}$ (Maciel-de-Freitas et al. 2006, Bhalala \& Arias 2009) and a worn sock emanating foot odour (Hiwat et al. 2011b). The BG-Sentinel ${ }^{\circledR}$ trap works well for the collection of African anophelines under seminatural conditions (Schmied et al. 2008). However, the BG-Sentinel ${ }^{\circledR}$ trap is not as efficient for collecting the anthropophilic Neotropical anopheline An. darlingi and enhancements have been tested in a collection method known as BG-Malaria to increase yields (Gama et al. 2013). Another widely used trap with combined simple molecules is the Mosquito Magnet ${ }^{\circledR}$. Some contemporary models of Mosquito Magnet ${ }^{\mathbb{R}}$ use $\mathrm{CO}_{2}+$ octenol as a synergic attractant (Takken \& Kline 1989, Kline et al. 1991). The advantage of the Mosquito Magnet ${ }^{\circledR}$ over the CDC light trap and the BG-Sentinel ${ }^{\circledR}$ is its functional longevity because it can function for weeks without batteries or propane replacement (Davis et al. 1995, Schmied et al. 2008, Kitau et al. 2009).

Human sweat molecules - Ammonia, lactic acid and carboxylic acids are among the compounds abundantly present in human sweat that have been tested as single molecules in anopheline collection methods, primarily for the African An. gambiae (Knols et al. 1997, Takken et al. 1997, Costantini et al. 1999, 2001, Healy \& Copland 2000, Braks et al. 2001, Hallem et al. 2004). Combined with $\mathrm{CO}_{2}$, molecules such as ammonia, lactic acid and carboxylic acid can effectively attract African anthropophilic anophelines (Mboera \& Takken 1997, Smallegange et al. 2005, Jawara et al. 2011). Tetradecanoic acid, a carboxylic acid, elicited an enhanced attraction of An. gambiae s.s. in olfactometer assays (Smallegange et al. 2009). Tetradecanoic acid, ammonia and L-lactic 
acid (commercially available as Lurex ${ }^{\circledR}$ ) were highly efficient attractants for An. gambiae s.s. when delivered together in laboratory experiments using the Mosquito Magnet ${ }^{\mathbb{R}}-X$ counterflow trap (Schmied et al. 2008). Trap tests for single molecules present in human sweat have not been found in the literature for Neotropical anthropophilic anophelines.

Complex molecules - Complex molecules, usually derived from human odours, can act as attractants for anthropophilic anophelines and other mosquitoes. These complex molecules remain largely unidentified and are used as a mix of undefined molecules. Odour attractants for mosquitoes have been investigated with the main objective of substituting for the live animals used as attractants in traps (Kline 1998, Ritchie et al. 2003, Dennett et al. 2004, Siphiprasasna et al. 2004, Bell et al. 2005, Njiru et al. 2006, Kitau et al. 2010). Nylon socks worn for at least $12 \mathrm{~h}$ by a human individual can attract significantly high numbers of anophelines (de Jong \& Knols 1995, Njiru et al. 2006, Qiu et al. 2007, Schmied et al. 2008, Smallegange et al. 2010). Interestingly, emanations from worn socks lasted for days, corroborating earlier findings that vacant domiciles previously occupied by humans or worn clothing are attractive to anthropophilic anophelines for a number of days (Haddow 1942). Limburger cheese has a characteristic smell resembling foot odour. Limburger cheese and moisture, limburger cheese and heat and limburger cheese moisture and heat have been found to be effective attractants to African malaria vectors (Knols \& de Jong 1996, Owino 2011). The chemical nature of the complex molecules present in both worn socks and smelly cheeses may be linked to the class of carboxylic acids. There are no references for the testing of human sweat in traps for Neotropical anthropophilic anophelines.

Resting boxes - Resting boxes use fresh or decayed cattle urine. Interestingly, most of the literature on resting boxes is from different parts of Africa and no studies have been conducted in the Neotropics (Odiere et al. 2007, Kweka et al. 2009, 2010, Mahande et al. 2010). Nonetheless, we list resting boxes in our review due to their extensive and recent use in Africa. Resting boxes use complex, undefined chemical attractants and colour and are classified as a chemical collection method. Resting boxes (Edman et al. 1997, Kweka et al. 2009, Sikulu et al. 2009, Govella et al. 2011) and clay pots (Odiere et al. 2007) have been assessed, mainly in Africa, for their efficacy at collecting different vectors and under distinct malaria epidemiological conditions. Resting boxes are simple tools and rely on the fact that mosquitoes gather together in dark and cool resting places during the day (Service 1977, Wayne 1989, Mboera 2005, Sikulu et al. 2009). However, resting boxes placed either in the intradomicile or in the extradomicile provide smaller surfaces than natural resting sites and, in most cases, yields are poor, with specimens becoming unidentifiable (Kay 1982, Burkett et al. 2008, Seyoum et al. 2012).

Knockdown - Indoor and resting anophelines can also be collected using a technique known as knockdown with the use of indoor pyrethrum spray onto white sheets from which dead female specimens are readily collected by suction mechanisms (Kulkarni et al. 2006, Odiere et al. 2007). Tests involving the knockdown technique have not been recorded for Neotropical anthropophilic anophelines.

Physical - Light - A light attractant involves the chemical interaction of photons that are perceived by receptor molecules in the eyes of the mosquito. Nonetheless, we classified light as a physical attractant due to the physical nature of the lamps used as light sources in traps. Insect light receptors are sensitive to wavelengths between 350-600 nm (Brioscoe \& Chittka 2001, Alencar et al. 2012) and light traps use lights with specific wavelengths to attract insects, including mosquitoes (Silveira-Neto et al. 1976, Forattini 2002). Light traps were first used in the United States of America (USA) in 1928 (Headlee 1928). Since then, light sources in traps have undergone many developments to increase mosquito collection efficiency (Service 1970, Chandler et al. 1975, Joshi et al. 1975), have been used as one of the most common attractants and are largely used in CDC light traps (Sudia \& Chamberlain 1962, Odetoyinbo 1969). Light traps are relatively reliable (Odetoyinbo 1969, Chandler et al. 1975, Zaim et al. 1986, Lines et al. 1991, Le Goff et al. 1993, Mbogo et al. 1993, Mathenge et al. 2004, 2005) and largely unaffected by the presence of insecticidal interventions (Magbity et al. 2002, Killeen et al. 2007). The CDC miniature light trap is widely used, even though yields are unspecific, because it catches a variety of mosquito species. To increase specificity, especially for African malaria vectors, CDC light traps have usually been placed beside occupied bed nets (Sudia \& Chamberlain 1962, Lines et al. 1991, Mbogo et al. 1993, Mboera et al. 1998). The attraction of mosquitoes to the human host inside the bed net increases the efficiency of the light trap (Garrett-Jones \& Magayuka 1975, Shiff et al. 1995, Mboera et al. 1998, Mathenge et al. 2002). Interestingly, the attraction of different anopheline population cohorts with distinct parity rates according to the trap position relative to the human occupying the bed has been reported (Mboera et al. 1998, Magbity \& Lines 2002, Killeen et al. 2007). The sampling efficiency of light traps for catching Neotropical anthropophilic anophelines was found to be density dependent, with its efficiency decreasing at high vector densities in Venezuela and in the USA (Rubio-Palis et al. 1999, Kaufman et al. 2008). In fact, trap tests in Suriname showed that the use of light in CDC traps gave non-specific results because it lured a variety of other mosquito species rather than anthropophilic anophelines (Hiwat et al. 2011b). In our experience, the use of the CDC trap is preferred without light for the collection of Neotropical anthropophilic anophelines.

Colour - As with light, colour is perceived by chemical receptor molecules in the eyes of the mosquito. However, colour as an attractant is placed in traps as sheets of plastic, fabric or plates and, for this reason, is classified as a physical attractant. Anophelines' colour preferences are not yet well understood. Although black colour (Bidlingmayer \& Hem 1980) and checked patterns (Hoel 
et al. 2011) in traps have been reported as better attractants for mosquitoes in general, white was the preferred colour of the Neotropical anthropophilic anopheline species An. darlingi (Gama et al. 2013).

The BG-Sentinel ${ }^{\mathbb{}}$ trap is herein classified as a physi$\mathrm{cal} / \mathrm{chemical}$ trap using colour as the main attractant even though BG-Sentinel ${ }^{\circledR}$ traps use heat and can be used with simple and complex molecule chemicals. The BGSentine $\mathrm{l}^{\mathbb{R}}$ and its variations may use contrasting black and white patterns and light-emitting diodes (LEDs) with green, blue, orange and purple colours and incandescent and ultraviolet (UV) lights (Burkett et al. 1998, Gama et al. 2013). As its heat source, the BG-Sentinel ${ }^{\mathbb{B}}$ trap employs an infrared, black plastic-encased heating element. Chemical attractants include $\mathrm{CO}_{2}(250 \mathrm{~mL} /$ min), Lurex $3^{\circledR}$ (American Biophysics, USA) and octenol, among others (Kaufman et al. 2008). The BG-Sentinel ${ }^{\circledR}$ trap has been modified, re-named the BG-Malaria trap (under further development) and tested in the field in the Brazilian Amazon (Gama et al. 2013). The efficiency of the Mosquito Sentinel trap remains to be tested for Neotropical anthropophilic anophelines. In one study, a BG-Malaria trap that used $\mathrm{CO}_{2}$ as attractant and showed higher yields for An. darlingi when the colour of the tested trap was entirely white (Gama et al. 2013).

Heat - Heating elements from infrared light are used in the Mosquito Magnet ${ }^{\circledR}$ type of traps. Heating convection waves are likely to be used as cues from mosquitoes to locate a blood source (Kline \& Lemire 1995). The Mosquito Magnet ${ }^{\circledR}$ trap also has a plume chamber into which octenol strips are placed. The use of a trap such as the Mosquito Magnet ${ }^{\mathbb{B}}$, which uses heat in combination with $\mathrm{CO}_{2}$ and octenol, attracts high numbers of the Neotropical anophelines species Anopheles nuneztovari and An. darlingi that are significantly correlated with human landing catch results (Rubio-Palis et al. 2012). The Mosquito Magnet ${ }^{\mathbb{B}}$ trap produces higher yields for Anopheles oswaldoi than human landing catches, but is not as efficient in collecting Anopheles marajoara (Rubio-Palis et al. 2012). The low yield for An. marajoara may be due to low population numbers for this species (Rubio-Palis et al. 2012). $\mathrm{CO}_{2}$-baited traps (Mosquito Magnet ${ }^{\circledR}, \mathrm{CDC}$, BG-Sentinel ${ }^{\mathbb{Q}}$ ) were shown to be inefficient in the collection of the Neotropical anthropophilic anophelines $A n$. aquasalis and An. darlingi (Hiwat et al. 2011a, b).

Physical/chemical - Currently, most commercially available mosquito traps use a combination of chemical and physical attractants. These different combinations of the above-mentioned biological, chemical and physical collection methods and attractants (Kline 2007, Silver \& Service 2008) have been tested to enhance efficiency (Smallegange et al. 2005).

The CDC, BG-Sentinel ${ }^{\circledR}$ and Mosquito Magnet ${ }^{\circledR}$ types of traps, for example, can use chemical attractants, such as octenol, carboxylic acids and worn socks, in combination with light and colour, together with the use of suction, to collect and store mosquitoes attracted, including anophelines.

Advantages and disadvantages of the different anopheline collection methods - The choice of anoph- eline collection method should be based on the actual human-biting mosquito population, thus increasing the reliability of the estimation of the real entomological inoculation rate (Mboera 2005). All anopheline collection methods have their advantages and disadvantages. For the anopheline collection methods classified as biological, the main advantage of the use of humans and animals is that it offers the most accurate representation of the relevant entomological parameters. The human landing catch, Shannon-type traps, bed net traps and exit and entry traps are classified here as biological anopheline collection methods. The main disadvantage of biological anopheline collection methods is the fact that human individuals are prone to becoming infected when serving as attractants. The human landing catch method also has the disadvantages of requiring training and having a high cost in terms of the human-hours of work involved.

Physical, chemical and physical/chemical anopheline collection methods have the advantages of being relatively low cost and of low ethical impact, requiring simple installation and maintenance; these methods are useful for improving the understanding of the spatiotemporal distribution of malaria vectors when human landing catches are not feasible.

Nonetheless, among the disadvantages of the physical, chemical and physical/chemical anopheline collection methods is the maintenance needed to ensure their continued effectiveness; for example, these methods require the regular recharging or changing of batteries, the replacement of chemical and physical sticks and propane tanks, the emptying of capture nets and the replacement and cleaning of adhesive boards and electric grids. Shannon-type tent traps are bulky, which makes setting them up and moving them difficult. However, a main disadvantage of the physical, chemical and physi$\mathrm{cal} / \mathrm{chemical}$ anopheline collection methods is their inefficiency in providing results that are useful in assessing entomological parameters of anthropophilic anophelines when compared to the results and efficiency obtained from the human landing catch method (Hiwat et al. 2011b, Overgaard et al. 2012).

The choice of an alternative method to the human landing catch for capturing anthropophilic malaria vectors must take into account the power of the anopheline collection method to essentially reproduce the results of the human attraction. Generally, all tested traps and attractants have displayed variable performances compared to human landing catches for anopheline sampling, especially in the case of Neotropical anopheline vectors of malaria. In fact, several efforts have been made in the search for more appropriate methods to collect anthropophilic anopheline vectors from the New World, such as An. darlingi, An. aquasalis, An. nuneztovari and Anopheles triannulatus s.l., but the results have been inconclusive (Eiras \& Jepson 1991, Rubio-Palis \& Curtis 1992, Rubio-Palis 1996, Rubio-Palis et al. 1999, 2012, Gama et al. 2007, 2013, Hiwat et al. 2011a, b, Missawa et al. 2011, JBP Lima et al., unpublished observations). Therefore, according to the most recent studies, the human landing catch is the collection method of choice for Neotropical anthropophilic anophelines. Nonetheless, 
it has also been concluded that the yields of anthropophilic anophelines can be enhanced by the use of human odour as an attractant in physical/chemical-type traps, such as the CDC without light (Hiwat et al. 2011a, b), the Mosquito Magnet ${ }^{\circledR}$ (Hiwat et al. 2011a, b, Rubio-Palis et al. 2012), the BG-Sentinel ${ }^{\circledR}$ (Hiwat et al. 2011a, b) or the BG-Malaria (Gama et al. 2013) traps and by the use of the biological-type traps, such as protected human collectors in Shannon-type traps (Hiwat et al. 2011b, Missawa et al. 2011, JBP Lima et al., unpublished observations). Based on these findings and conclusions, we formulated questions and carried out experiments years ago that we will describe and discuss in the following section.

Which collection method is most appropriate? Is there a trap to collect anthropophilic anophelines as a replacement for the human landing catch that is able to provide parameters essential to evaluating and understanding malaria transmission dynamics in a given area? Are there yield differences in distinct areas? - To answer these questions and in an attempt to provide an improved an effective methodology for capturing anthropophilic anophelines, several collection methods have been conducted. In our decades-long experience collecting mosquitoes for taxonomical, biological and parasitological studies, we have established our own preferences regarding anopheline collection methods. Like most authors, we have noticed that human landing catches are simple and efficient, but that Shannon-type traps may also present high performances with respect to anopheline yields. We wondered whether we could assess these collection methods and use our long-standing experience to modify them to increase the collection efficiency for anthropophilic anophelines in distinct epidemiological scenarios.

We then carried out comparative collections of anthropophilic anophelines and compared the collection methods with the traditional method of the human landing catch. Special attention was given to the quality and quantity of anopheline species collected in three comparisons in distinct malaria epidemiological conditions in Brazil.

Three comparisons - Several collection methods were evaluated in three comparisons in the Brazilian Amazon. We conducted the comparisons at the end of the 1990s (Fig. 2). The first comparison consisted of seven collection methods carried out in a medium-high anopheline population density and highly malaria-endemic area. The second comparison consisted of the two collection methods with the highest anopheline yields of the first comparison plus four other collection methods evaluated in the same high anopheline population density and highly malaria-endemic area. The third comparison consisted of the two collection methods with the highest anopheline yields in the second comparison plus two other collection methods. The third comparison was carried out in a malaria-endemic area subject to heavy insecticide spraying. Because of this heavy insecticide spraying at the time of comparison, the area presented a low number of malaria cases and low anopheline population density.

First comparison - The first comparison was conducted during 1996 on Peixoto Farm in the municipal- ity of Peixoto de Azevedo, state of Mato Grosso, Brazil $\left(10^{\circ} 13^{\prime} 12^{\prime \prime} \mathrm{S} 54^{\circ} 58^{\prime} 12^{\prime \prime} \mathrm{W}\right)$. Peixoto de Azevedo is a nonurban, highly malaria-endemic area with moderate use of insecticide spraying and a medium to high anopheline population density. Anopheline collections were carried out on Peixoto Farm, a cattle breeding farm in the rural area $\sim 3 \mathrm{~km}$ from Peixoto de Azevedo. The seven collection methods compared in the first stage comprised the human landing catch, a traditional Shannon trap and five CDC-type traps (CDC white LED light, CDC UV light, $\mathrm{CDC} \mathrm{CO}_{2}, \mathrm{CDC} \mathrm{CO}_{2}+$ octenol-1, CDC light + octenol-1) that were established $50 \mathrm{~m}$ from each other during seven consecutive nights (Fig. 2). The initial distribution of the collection method sites was random and was rotated clockwise in the subsequent captures to avoid sampling bias (Beaty \& Marquardt 1996). Collections started at sunset, at approximately 06:00 pm and lasted for $4 \mathrm{~h}$. Each collection lasted for 40 min with $20 \mathrm{~min}$ intervals between collections. Mosquitoes were identified (Faran \& Linthicum 1981) and parity status evaluation checked for at least $10 \%$ of the females. A total of 1,507 anoph-

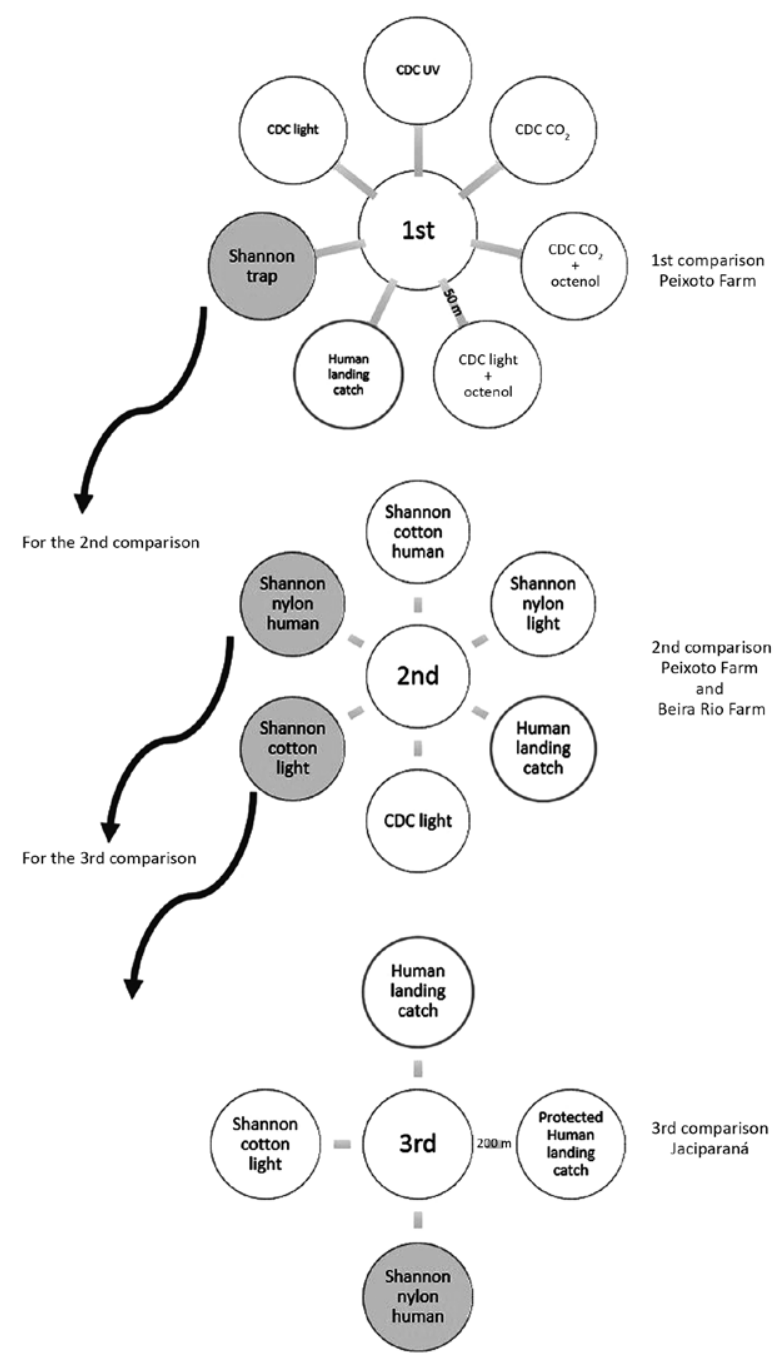

Fig. 2: methodology used in three comparisons of anopheline collection methods in Brazil. $\mathrm{CO}_{2}$ : carbon dioxide; UV: ultraviolet light. 
eline specimens belonging to 11 species were collected. The most frequent species found were Anopheles strodei (27\%), An. triannulatus (18.7\%), An. darlingi (16.7\%), An. marajoara (13.5\%) and An. nuneztovari (11.6\%) (Table I).

When the total number of anophelines collected by each type of collection method was verified, the results showed that a Shannon trap built with nylon and using a human individual as the attractant was as efficient as the human landing catch $(p>0.05)$. For the anophelines in the studied areas, all of the CDC-type traps performed poorly. Low anopheline collection efficiency was observed even when attractants previously seen as powerful were used, such as $\mathrm{CO}_{2}+$ octenol + UV (Table I). Although $\mathrm{An}$. darlingi was also caught in slightly higher numbers in the nylon-built Shannon trap using a human as attractant, when compared to the human landing catch, this finding was not statistically significant for the species alone ( $p>$ 0.05 ) (Table I). Because the Shannon trap was the anopheline collection method with the highest yield in the first comparison, including for An. darlingi, it was selected to be assessed in the second comparison.

Second comparison - The second comparison was also held in 1996 in two farms - the Peixoto Farm and the Beira Rio Farm - both in Peixoto de Azevedo. The Beira Rio Farm $\left(10^{\circ} 09^{\prime} 34^{\prime \prime} \mathrm{S} 55^{\circ} 00^{\prime} 22^{\prime \prime} \mathrm{W}\right)$ was located $\sim 7 \mathrm{~km}$ from the Peixoto Farm and $\sim 8 \mathrm{~km}$ from Peixoto de Azevedo in what is considered a mining area. The anopheline collection methods used were the human landing catch $(2 \mathrm{hu}-$ man individuals), a CDC light trap and four versions of the Shannon trap that was the anopheline collection method with the highest yield from the first comparison, for a total of six collection methods for the second comparison.
The Shannon trap was made out of cotton and nylon and used light and a human as attractants (Fig. 2).

At Beira Rio Farm, 6,185 specimens of anophelines were collected belonging to 10 species. The most frequent anopheline species was An. darlingi, representing $67.3 \%$ of the total specimens captured, followed by $A n$. nuneztovari, An. triannulatus and An. marajoara, which accounted for $20.6 \%, 4.2 \%$ and $3.4 \%$ of the specimens, respectively (Table II).

At Beira Rio Farm, the Shannon-type traps collected the highest number of anophelines (Fig. 3). The Shannon trap made of nylon with a protected human collector inside had the highest yield for An. darlingi (Fig. 3).

At Peixoto Farm, the second comparison resulted in 2,630 specimens of Anopheles. These anophelines belonged to 13 species, of which the most frequent were $A n$. darlingi, accounting for $39.4 \%$ of the total and $A n$. marajoara and An. rangeli contributing $14 \%$ and $13.5 \%$ of the specimens, respectively (Table III).

During the second comparison on Peixoto Farm, a Shannon trap built with cotton using light as an attractant was the collection method with the highest yield when the total number of anophelines was considered (Fig. 3). For An. darlingi during the second comparison on Peixoto Farm, the Shannon trap built with cotton using light as the attractant was also the collection method with the highest yield (Fig. 3).

Therefore, for both Beira Rio Farm and Peixoto Farm, the two collection methods with the highest yield of total anophelines were Shannon traps (Fig. 3). The nylon-built Shannon trap using a human as attractant $(50 \%$ on Beira Rio Farm and $20 \%$ on Peixoto Farm) and the cotton-built

\section{TABLE I}

Number of anophelines caught using seven collection methods during the first comparison during seven consecutive nights at sunset for $4 \mathrm{~h}(40 \mathrm{~min}+20 \mathrm{~min}$ interval) in a total of $18.7 \mathrm{~h}$ of collection in 1996 , Peixoto Farm, municipality of Peixoto de Azevedo, state of Mato Grosso, Brazil

\begin{tabular}{|c|c|c|c|c|c|c|c|c|}
\hline Anopheline species & $\begin{array}{c}\text { Human } \\
\text { landing } \\
\text { catch } \\
\mathrm{n}(\%)\end{array}$ & $\begin{array}{c}\text { Shannon } \\
\text { nylon } \\
\text { human } \\
\text { n (\%) }\end{array}$ & $\begin{array}{c}\mathrm{CDC} \mathrm{CO}_{2} \\
+ \\
\text { octenol } \\
\mathrm{n}(\%)\end{array}$ & $\begin{array}{c}\text { CDC UV } \\
\text { n (\%) }\end{array}$ & $\begin{array}{c}\mathrm{CDC} \text { light } \\
+ \\
\mathrm{CO}_{2} \\
\mathrm{n}(\%)\end{array}$ & $\begin{array}{c}\text { CDC light } \\
\mathrm{n}(\%)\end{array}$ & $\begin{array}{c}\text { CDC light } \\
+ \\
\text { octenol } \\
\mathrm{n}(\%)\end{array}$ & $\begin{array}{c}\text { Total } \\
\text { (n) }\end{array}$ \\
\hline An. strodei & $220(54.1)$ & $125(30.7)$ & $58(14.3)$ & $2(0.5)$ & $2(0.5)$ & $0(0)$ & $0(0)$ & 407 \\
\hline An. marajoara & $116(57.1)$ & $54(26.6)$ & $23(11.3)$ & $4(2)$ & $5(2.5)$ & $0(0)$ & $1(0.5)$ & 203 \\
\hline An. darlingi & $111(44)$ & $136(54)$ & $1(0.4)$ & $4(1.6)$ & $0(0)$ & $0(0)$ & $0(0)$ & 252 \\
\hline An. triannulatus & $100(35.6)$ & $179(63.7)$ & $0(0)$ & $0(0)$ & $2(0.7)$ & $0(0)$ & $0(0)$ & 281 \\
\hline An. nuneztovari & $92(52.6)$ & $71(40.6)$ & $3(1.7)$ & $7(4)$ & $0(0)$ & $2(1.1)$ & $0(0)$ & 175 \\
\hline An. rangeli & $57(45.2)$ & $68(54)$ & $0(0)$ & $0(0)$ & $1(0.8)$ & $0(0)$ & $0(0)$ & 126 \\
\hline An. oswaldoi & $9(23.7)$ & $29(76.3)$ & $0(0)$ & $0(0)$ & $0(0)$ & $0(0)$ & $0(0)$ & 38 \\
\hline An. argyritarsis & $7(100)$ & $0(0)$ & $0(0)$ & $0(0)$ & $0(0)$ & $0(0)$ & $0(0)$ & 7 \\
\hline An. benarrochi & $4(80)$ & $1(20)$ & $0(0)$ & $0(0)$ & $0(0)$ & $0(0)$ & $0(0)$ & 5 \\
\hline An. rondoni & $2(22.2)$ & $7(77.8)$ & $0(0)$ & $0(0)$ & $0(0)$ & $0(0)$ & $0(0)$ & 9 \\
\hline An. evansae & $0(0)$ & $4(100)$ & $0(0)$ & $0(0)$ & $0(0)$ & $0(0)$ & $0(0)$ & 4 \\
\hline Total & $718(47.6)$ & $674(44.7)$ & $85(5.6)$ & $17(1.1)$ & $10(0.7)$ & $2(0.1)$ & $1(0.1)$ & 1,507 \\
\hline
\end{tabular}

$\mathrm{CO}_{2}$ : carbon dioxide; $\mathrm{UV}$ : ultraviolet light. 
TABLE II

Number of anophelines caught using six collection methods during the second comparison during six consecutive nights at sunset for $4 \mathrm{~h} \mathrm{(40} \mathrm{min}+20 \mathrm{~min}$ interval) in a total of $16 \mathrm{~h}$ of collection in 1996, in Beira Rio Farm, municipality of Peixoto de Azevedo, state of Mato Grosso, Brazil

\begin{tabular}{|c|c|c|c|c|c|c|c|c|}
\hline Anopheline species & $\begin{array}{c}\text { Human } \\
\text { landing catch } \\
\text { individual } 1 \\
\mathrm{n}(\%)\end{array}$ & $\begin{array}{c}\text { Human } \\
\text { landing catch } \\
\text { individual } 2 \\
\mathrm{n}(\%)\end{array}$ & $\begin{array}{l}\text { Shannon } \\
\text { nylon } \\
\text { human } \\
\text { n (\%) }\end{array}$ & $\begin{array}{l}\text { Shannon } \\
\text { cotton } \\
\text { human } \\
\mathrm{n}(\%)\end{array}$ & $\begin{array}{l}\text { Shannon } \\
\text { nylon } \\
\text { light } \\
\text { n (\%) }\end{array}$ & $\begin{array}{c}\text { Shannon } \\
\text { cotton } \\
\text { light } \\
\mathrm{n}(\%)\end{array}$ & $\begin{array}{c}\text { CDC light } \\
\mathrm{n}(\%)\end{array}$ & $\begin{array}{c}\text { Total } \\
\text { (n) }\end{array}$ \\
\hline An. darlingi & $373(9)$ & $305(7.3)$ & $2,291(55)$ & $124(3)$ & $262(6.3)$ & $797(19.1)$ & $10(0.2)$ & 4,162 \\
\hline An. marajoara & $36(17)$ & $57(26.9)$ & $52(24.5)$ & $4(1.9)$ & $1(0.5)$ & $61(28.8)$ & $1(0.5)$ & 212 \\
\hline An. rangeli & $4(6.9)$ & $7(12.1)$ & $25(43.1)$ & $3(5.2)$ & $0(0)$ & $19(32.8)$ & $0(0)$ & 58 \\
\hline An. strodei & $16(10.9)$ & $17(11.6)$ & $52(35.4)$ & $7(4.8)$ & $5(3.4)$ & $50(34)$ & $0(0)$ & 147 \\
\hline An. evansae & $0(0)$ & $0(0)$ & $0(0)$ & $0(0)$ & $0(0)$ & $3(100)$ & $0(0)$ & 3 \\
\hline An. triannulatus & $15(5.7)$ & $33(12.6)$ & $150(57.3)$ & $9(3.4)$ & $5(1.9)$ & $50(19.1)$ & $0(0)$ & 262 \\
\hline An. nuneztovari & $46(3.6)$ & $161(12.6)$ & 458 (35.9) & $27(2.1)$ & $77(6)$ & $505(39.6)$ & $0(0)$ & 1,274 \\
\hline An. oswaldoi & $11(17.5)$ & $4(6.3)$ & $25(39.7)$ & $3(4.8)$ & $1(1.6)$ & $19(30.2)$ & $0(0)$ & 63 \\
\hline An. rondoni & $1(33.3)$ & $1(33.3)$ & $0(0)$ & $0(0)$ & $0(0)$ & $1(33.3)$ & $0(0)$ & 3 \\
\hline An. mediopunctatus & $0(0)$ & $1(100)$ & $0(0)$ & $0(0)$ & $0(0)$ & $0(0)$ & $0(0)$ & 1 \\
\hline Total & $502(8.1)$ & $586(9.5)$ & $3,053(49.4)$ & 177 (2.9) & $351(5.7)$ & $1,505(24.3)$ & $11(0.2)$ & 6,185 \\
\hline
\end{tabular}
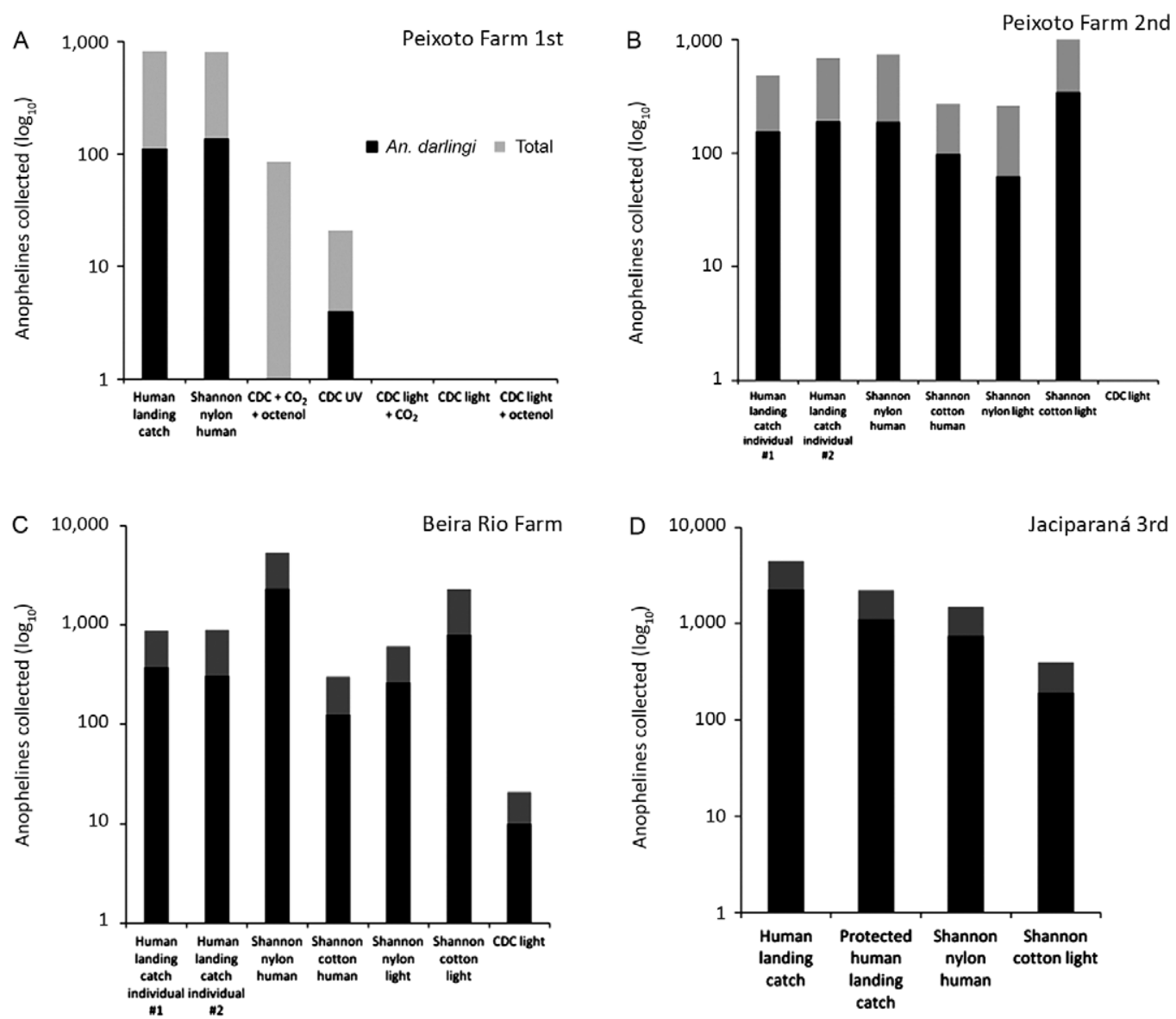

Fig. 3A, B: Anopheles darlingi and total anophelines collected by type of collection method during the first and second comparison, respectively, in 1996, in Peixoto Farm, municipality of Peixoto de Azevedo, state of Mato Grosso (MT), Brazil; C: during the second comparison in 1996, in Beira Rio Farm (MT); D: during the third comparison in 1999, in Jaciparaná, state of Rondônia, Brazil; $\mathrm{CO}_{2}$ : carbon dioxide. 


\section{TABLE III}

Number of anophelines caught using six collection methods during the second comparison during six consecutive nights at sunset for $4 \mathrm{~h}(40 \mathrm{~min}+20 \mathrm{~min}$ interval) in a total of $16 \mathrm{~h}$ of collection in 1996, Peixoto Farm, municipality of Peixoto de Azevedo, state of Mato Grosso, Brazil

\begin{tabular}{|c|c|c|c|c|c|c|c|c|}
\hline Anopheline species & $\begin{array}{c}\text { Human } \\
\text { landing } \\
\text { catch } 1 \\
\text { n (\%) }\end{array}$ & $\begin{array}{c}\text { Human } \\
\text { landing } \\
\text { catch } 2 \\
\text { n (\%) }\end{array}$ & $\begin{array}{c}\text { Shannon } \\
\text { nylon } \\
\text { human } \\
\text { n }(\%)\end{array}$ & $\begin{array}{c}\text { Shannon } \\
\text { cotton } \\
\text { human } \\
\text { n }(\%)\end{array}$ & $\begin{array}{c}\text { Shannon } \\
\text { nylon } \\
\text { light } \\
\text { n }(\%)\end{array}$ & $\begin{array}{c}\text { Shannon } \\
\text { cotton } \\
\text { light } \\
\text { n }(\%)\end{array}$ & $\begin{array}{c}\text { CDC light } \\
\mathrm{n}(\%)\end{array}$ & $\begin{array}{l}\text { Total } \\
\mathrm{n}(\%)\end{array}$ \\
\hline An. darlingi & $155(14.9)$ & $190(18.3)$ & $188(18.1)$ & $98(9.5)$ & $62(6)$ & $344(33.2)$ & $0(0)$ & $1,037(39.4)$ \\
\hline An. marajoara & $69(18.5)$ & $90(24.1)$ & $77(20.6)$ & $5(1.3)$ & $19(5.1)$ & $113(30.3)$ & $0(0)$ & $373(14.2)$ \\
\hline An. strodei & $30(12)$ & 49 (19.6) & $63(25.2)$ & $9(3.6)$ & $20(8)$ & 79 (31.6) & $0(0)$ & $250(9.5)$ \\
\hline An. rangeli & $25(7)$ & $78(22)$ & $93(26.2)$ & $21(5.9)$ & $20(5.6)$ & $118(33.2)$ & $0(0)$ & $355(13.5)$ \\
\hline An. evansae & $22(13.2)$ & $38(22.8)$ & $37(22.2)$ & $8(4.8)$ & $3(1.8)$ & $59(35.3)$ & $0(0)$ & $167(6.3)$ \\
\hline An. nuneztovari & $17(12.4)$ & $13(9.5)$ & 27 (19.7) & 19 (13.9) & $37(27)$ & $24(17.5)$ & $0(0)$ & $137(5.2)$ \\
\hline An. triannulatus & $8(6.7)$ & $32(26.7)$ & $44(36.7)$ & $4(3.3)$ & $6(5)$ & $26(21.7)$ & $0(0)$ & $120(4.6)$ \\
\hline An. argyritarsis & $3(75)$ & $0(0)$ & $0(0)$ & $0(0)$ & $1(25)$ & $0(0)$ & $0(0)$ & $4(0.2)$ \\
\hline An. oswaldoi & $1(2.5)$ & $4(10)$ & $19(47.5)$ & $1(2.5)$ & $2(5)$ & $13(32.5)$ & $0(0)$ & $40(1.5)$ \\
\hline An. rondoni & $1(4)$ & $2(8)$ & $5(20)$ & $2(8)$ & $5(20)$ & $10(40)$ & $0(0)$ & $25(1)$ \\
\hline An. benarrochi & $0(0)$ & $2(28.6)$ & $0(0)$ & $0(0)$ & $5(71.4)$ & $0(0)$ & $0(0)$ & $7(0.3)$ \\
\hline An. minor & $0(0)$ & $0(0)$ & $0(0)$ & $7(6.1)$ & $21(18.4)$ & $86(75.4)$ & $0(0)$ & $114(4.3)$ \\
\hline An. mattogrossensis & $0(0)$ & $0(0)$ & $0(0)$ & $0(0)$ & $0(0)$ & $1(100)$ & $0(0)$ & $1(0)$ \\
\hline Total & $331(12.6)$ & $498(18.9)$ & $553(21)$ & $174(6.6)$ & $201(7.6)$ & $873(33.2)$ & $0(0)$ & $2,630(100)$ \\
\hline
\end{tabular}

Shannon trap using light as the attractant $(24 \%$ on Beira Rio Farm and $33 \%$ on Peixoto Farm) showed the highest yields when compared to the human landing catch. For An. darlingi, when compared to the human landing catch method, the highest yields were observed for the Shannon nylon trap with human attractant and the Shannon cotton trap with light as the attractant, irrespective of the area and epidemiological malaria conditions (Fig. 3).

From our perspective, these results indicate that when anopheline density is high and reaches a threshold, the human landing catch is not particularly efficient. We believe that this is due to the decreased collection capacity of the collector when facing a high number of mosquitoes. In these situations, Shannon-type traps can be more efficient.

Whereas in the human landing catch, the average percentage of An. darlingi collected for two human collectors was $8.2 \%$, the Shannon nylon trap with human attractant collected $55 \%$ and the Shannon cotton trap with light as an attractant collected 19\%, higher efficiencies than the human landing catch. Would the results for the different anopheline collection methods represent a distinct malaria epidemiological situation? The Shannon trap made out of cotton using light and the Shannon trap made out of nylon with a human as bait were the highest yielding anopheline collection methods in the second comparison (Fig. 2) and were selected to be assessed in the third comparison.

Third comparison - To evaluate whether the efficiency of anophelines yields could be compared for a distinct malaria epidemiological condition, a third comparison was conducted years later, in 1999, taking into account the results found in Peixoto de Azevedo, in the municipality of Jaciparaná, state of Rondônia, Brazil (09¹5'13'S $\left.64^{\circ} 24^{\prime} 28^{\prime \prime} \mathrm{W}\right)$. Jaciparaná was then characterised as an urban area with high malaria endemicity and constant/ intensive insecticide spraying (JBP Lima, unpublished observation). Due to the continuous insecticide spraying for malaria vector control, Jaciparaná presented a low anopheline population density. Four collection methods were evaluated in the third comparison: a Shannon trap made out of cotton using light as the attractant, a Shannon trap made out of nylon with a human as attractant, a protected human landing catch and human landing catch. In the protected human landing catch, the human collector wore a thick black sock on both legs and proceeded as in the human landing catch method. This procedure enabled the collector to capture the anophelines before biting took place. Anopheline collections were carried out in an urban area inside Jaciparaná. The sites of the four collection methods were placed $200 \mathrm{~m}$ apart from each other in the peridomicile of four domiciles and were carried out in four different months of the year (February, April, August and November 1999) (Fig. 2) in a four-night collection period during these four months. A total of 4,334 anophelines were collected. Out of these, 4,313, or $99.52 \%$, were $A n$. darlingi. Monthly percentages varied (Table IV).

From the total collected anophelines, 52.8\% $(2,265)$ were collected in the human landing catches, $25.9 \%$ $(1,110)$ in the protected human landing catches and $17.4 \%$ in the Shannon nylon traps with a human as the attractant and only $4 \%$ in the Shannon cotton traps with light as the attractant. Similar percentages were observed in the different months (Table IV). 


\section{TABLE IV}

Number of anophelines caught using four collection methods, four-night collection during four months, at sunset for $4 \mathrm{~h}(40 \mathrm{~min}+20 \mathrm{~min}$ interval) in a total of $10.7 \mathrm{~h}$ of collection per month and $428 \mathrm{~h}$ for the four months per type of collection method in a third comparison in 1999, Jaciparaná, state of Rondônia, Brazil

\begin{tabular}{|c|c|c|c|c|c|c|}
\hline Anopheline species & $\begin{array}{c}\text { Month } \\
\text { (4 nights/month) }\end{array}$ & $\begin{array}{l}\text { Human } \\
\text { landing catch } \\
\text { (n) }\end{array}$ & $\begin{array}{l}\text { Protected human } \\
\text { landing catch } \\
\text { (n) }\end{array}$ & $\begin{array}{l}\text { Shannon } \\
\text { nylon human } \\
\text { (n) }\end{array}$ & $\begin{array}{l}\text { Shannon } \\
\text { cotton light } \\
\text { (n) }\end{array}$ & $\begin{array}{c}\text { Total } \\
\text { (n) }\end{array}$ \\
\hline An. darlingi & February & 678 & 304 & 208 & 111 & 1,301 \\
\hline An. nuneztovari & & 0 & 0 & 1 & 3 & 4 \\
\hline An. evansae & & 0 & 0 & 0 & 7 & 7 \\
\hline An. darlingi & April & 1,241 & 723 & 428 & 74 & 2,466 \\
\hline An. nuneztovari & & 0 & 1 & 1 & 0 & 2 \\
\hline An. evansae & & 0 & 0 & 2 & 5 & 7 \\
\hline An. darlingi & August & 154 & 60 & 36 & 2 & 252 \\
\hline An. nuneztovari & & 0 & 0 & 0 & 0 & 0 \\
\hline An. evansae & & 0 & 0 & 0 & 1 & 1 \\
\hline An. darlingi & November & 192 & 23 & 74 & 5 & 294 \\
\hline An. nuneztovari & & 0 & 0 & 0 & 0 & 0 \\
\hline An. evansae & & 0 & 0 & 0 & 0 & 0 \\
\hline Total & & 2,265 & 1,111 & 750 & 208 & 4,334 \\
\hline
\end{tabular}

In Jaciparaná, the nylon-built Shannon trap using a human as bait and the cotton-built Shannon trap using light as the attractant followed the human landing catch and maintained the human landing catch yields both for total anophelines collected as well as for $A n$. darlingi (Fig. 3, Table IV).

The parity of $A n$. darlingi from the three different localities showed a significantly higher percentage of parous females in Jaciparaná $(\mathrm{p}<0.05)$. Differences in parity by type of collection method were not significant $(\mathrm{p}>0.05)$ (Fig. 4, Table V).

In summary, when evaluating variations of the Shannon trap and the CDC trap against the human landing catch with respect to the qualitative and quantitative yields for anthropophilic anopheline species, the Shannon-type traps using humans and colour as attractants were the collection methods with the highest yields (Fig. 5A).

The Shannon-type traps were shown to be a valuable tool for collecting An. darlingi in high densities when a human collector cannot capture swarms of females actively seeking a blood meal, a common occurrence in the Brazilian Amazon (Fig. 5A, B). In one of our collections, for example, a Shannon trap collected thousands of anopheline specimens in only $1 \mathrm{~h}$ of capture (JBP Lima, unpublished observation). It would not be possible for a single collector using the human landing catch method to collect this number of anopheline specimens. The Shannon trap was efficient in collecting a large number of mosquitoes, but, interestingly, the Shannon trap was also able to attract and collect An. darlingi in lowdensity situations.

The different results might be tentatively explained by the spatially and temporally distinct epidemiological conditions in Brazil. Peixoto de Azevedo, for example,

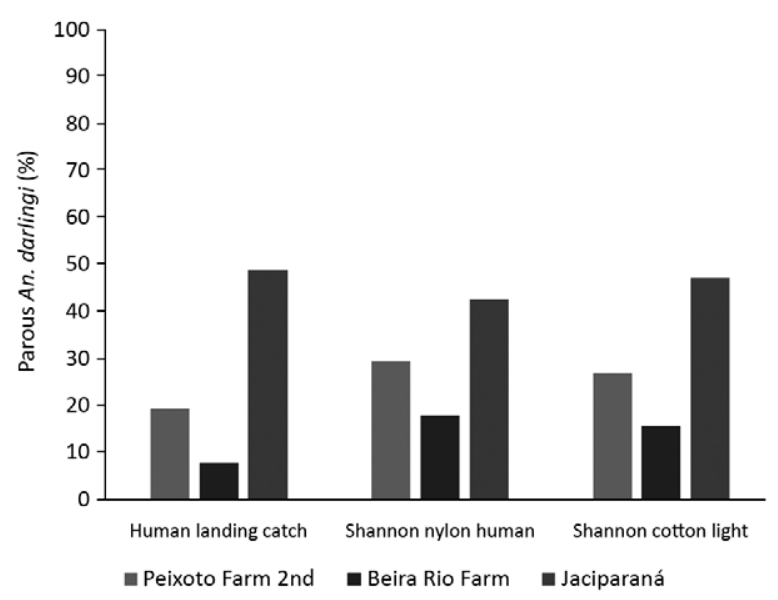

Fig. 4: percentage of parous Anopheles darlingi females caught in three different collection methods in three localities in Brazil.

a non-urban malaria-endemic area with high mosquito population densities, a high diversity of anopheline species and moderate use of insecticide spraying, showed different anopheline yields for the various collection methods for the first and second comparisons. Jaciparaná, in contrast, an urban non-malaria-endemic area with low mosquito density, low anopheline species diversity and intensive insecticide spraying, showed different results for the same collection methods used in Peixoto de Azevedo. In Peixoto de Azevedo, the Shannon trap built with nylon and using a human as the attractant produced the highest number of anophelines when compared to the human landing catch in the first compari- 
TABLE V

Percentage of parous Anopheles darlingi females caught during 1996-1999 using three different collection methods in three localities in Brazil

\begin{tabular}{|c|c|c|c|c|c|c|c|c|}
\hline \multirow{2}{*}{$\begin{array}{l}\text { Locality } \\
\text { Collection method }\end{array}$} & \multicolumn{2}{|c|}{ Peixoto Farm } & \multicolumn{2}{|c|}{ Beira Rio Farm } & \multicolumn{2}{|c|}{ Jaciparaná } & \multicolumn{2}{|c|}{ Total } \\
\hline & $\begin{array}{l}\text { Dissected } \\
\text { (n) }\end{array}$ & $\begin{array}{c}\text { Parous } \\
\text { n }(\%)\end{array}$ & $\begin{array}{l}\text { Dissected } \\
\text { (n) }\end{array}$ & $\begin{array}{c}\text { Parous } \\
\text { n }(\%)\end{array}$ & $\begin{array}{c}\text { Dissected } \\
\text { (n) }\end{array}$ & $\begin{array}{c}\text { Parous } \\
\text { n }(\%)\end{array}$ & $\begin{array}{c}\text { Total } \\
\text { dissected } \\
\text { (n) }\end{array}$ & $\begin{array}{c}\text { Total } \\
\text { parous } \\
\mathrm{n}(\%)\end{array}$ \\
\hline Human landing catch & 174 & $34(19.5)$ & 86 & $7(8.1)$ & 609 & $297(48.8)$ & 869 & $338(38.9)$ \\
\hline Shannon nylon human & 95 & $28(29.5)$ & 243 & $44(18.1)$ & 265 & $113(42.6)$ & 603 & $185(30.68)$ \\
\hline Shannon cotton light & 166 & $45(27.1)$ & 89 & $14(15.73)$ & 72 & $34(47.2)$ & 327 & $93(28.44)$ \\
\hline Total & 435 & $107(76.1)$ & 418 & $65(41.93)$ & 946 & $444(138.6)$ & 1,799 & $616(34.24)$ \\
\hline
\end{tabular}
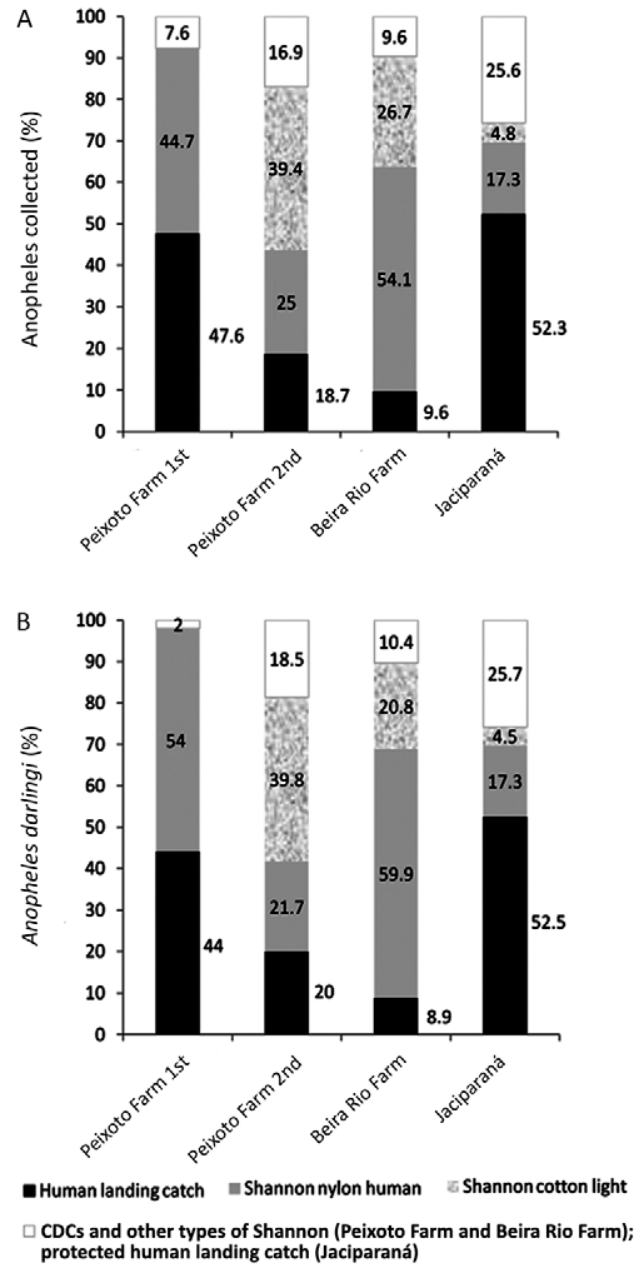

Fig. 5: percentage of anophelines (A) and of Anopheles darlingi (B) collected showing relative efficiency of the different anopheline collection methods in relation to total anophelines (A) and in relation to total Anopheles darlingi (B) caught using in three localities in Brazil. For Peixoto Farm, in the first comparison, Shannon cotton with light as attractant was not tested; in Peixoto Farm for the second comparison, the human landing catch depicted value is an average of anophelines caught by collectors 1 and 2. In Jaciparaná, protected human landing catch was tested as a fourth collection method (Table IV). son. Nonetheless, a few months later, during the second comparison, the Shannon trap built with cotton and using light as the attractant showed the highest yield at the same collection point in Peixoto de Azevedo. In contrast, in Jaciparaná, the nylon Shannon trap using a human as the attractant was the trap with the highest yields after the protected human landing catch. These results show that different anopheline collection strategies might have to be adopted for different epidemiological situations prevailing in highly malaria-endemic areas that are distinct in both in space and time. For instance, we know that highly anthropophilic and endophilic behaviour, such as that presented by An. gambiae s.s. in Africa, is unlikely for any of the Neotropical vectors, including An. darlingi in Brazil. Thus, for Neotropical anophelines, is there a most suitable collection method that should be employed for a given entomological parameter, another suitable for following transmission dynamics and another suitable for assessing control methods, taking into the account epidemiological characteristics of the area? To be reliable, any anopheline collection method should be able to estimate the vector's biting rates in a sufficiently sensitive manner. Sensitivity, therefore, is a factor of sampling efficiency that for the time being is calculated by comparison with results produced by the human landing catch. The efficiency of collection methods is influenced by the epidemiological characteristics of the area related to the landscape, the resident anophelines and humans, human culture and human behaviour (Gillies \& de Meillon 1968, Ijumba et al. 2002, Mahande et al. 2007, Kweka et al. 2009). These local characteristics may influence reliable, representative, consistent and epidemiologically meaningful entomological parameters of the anopheline vector populations. In the Neotropics, the collection efficiency for the different methods seems to be dependent on anopheline density. When anopheline density is very high, a nylon-built Shannon trap using a human as the attractant followed by a cotton-built Shannon trap using light as the attractant were more efficient than the human landing catch (Table II). Nonetheless, in moderate density, collection efficiency was not as high as that of the human landing catch (Table III). When anopheline den- 
sity is low, however, collection efficiency is better for the human landing catch. Therefore, thus far, out of the many collection methods that have been used in the Neotropics, none of them have qualitatively and quantitatively surpassed the human landing catch in its efficacy in capturing anthropophilic anophelines, mainly represented by An. darlingi when in low to moderate density (Fig. 5B).

Different collection methods may lead to different results - Different anopheline collection methods may lead to heterogeneous and incomparable results for distinct prevailing malaria transmission conditions in a given area. The need for regular anopheline sampling across wider geographical areas to include a more diverse range of environmental settings has been previously emphasised (Brown et al. 2008, Kelly-Hope \& McKenzie 2009). We believe that distinct epidemiological situations require different, yet comparable, approaches, such as the use of an anopheline collection method of choice for every particular situation.

Collection methods should be species-specific - Previous knowledge regarding the biology of anophelines is important when choosing the collection method. A great portion of anopheline species that are malaria vectors are highly anthropophilic. Some malaria vector species, however, exhibit an eclectic behaviour of sucking blood from both animals and humans. This is true, for instance, for the exophilic and zoophilic Anopheles sinensis (Lee et al. 2009). In another example, collection methods based on light attraction in combination with odour attractants have been found to lure particular species from a greater area than $\mathrm{CO}_{2}$ alone (Gillies \& Wilkes 1970) and distinct $\mathrm{CO}_{2}$ concentrations and non$\mathrm{CO}_{2}$ attractants combinations have been found to attract different members of the An. gambiae complex (Dekker $\&$ Takken 1998). Additionally, the use of an incandescent light in CDC traps may enhance the attraction of Anopheles aconitus (Das et al. 1993). Therefore, knowing the particularities of the study area, including the species targeted, is of key importance in the choice of appropriate collection methods and in the understanding of the results of the captures.

Interestingly, in most highly malaria-endemic areas in Brazil, anthropophilic anophelines do not present high population density. Is this due to the immediate action of insecticide application conducted by the control services in Brazil? We believe so. Thus far, insecticide sprayings are readily deployable in Brazil, mainly in urban and periurban areas, where access and logistics are greatly facilitated.

The human landing catch is the most accurate anopheline collection method - Alternative methods to the human landing catch, for more productive traps in relation to mosquito yield and less exposure for the human collector, have long been sought. Specifically for Latin America and the Caribbean, attempts to find a suitable trap for anthropophilic anophelines with these characteristics date to the early 1940s (Pritchard \& Pratt 1944, Bustamante \& Pires 1949) and continue to the present (Wilton 1975, Lourenço-de-Oliveira 1984, Sexton et al. 1986, Rubio-
Palis \& Curtis 1992, Rubio-Palis 1996, Rubio-Palis et al. 1999, JBP Lima et al., unpublished observations).

Currently, no collection method is as precise, accurate or representative of the human-biting rates of anthropophilic anophelines as the human landing catch.

The human landing catch remains the standard anthropophilic anopheline collection method - In Brazil, as in the rest of the world, of the many collection methods used to attract and capture anophelines, the human landing catch remains the method with the highest yield for anthropophilic vector species, such as An. darlingi, mainly in low to moderate anopheline population densities. The human landing catch is a collection method that primarily targets active host-seeking anthropophilic anopheline females and is the method of choice for quantifying entomological parameters essential for evaluating and understanding malaria transmission dynamics, such as biting rates, the degree of anthropophily, human exposure and transmission rates. However, the collection of intradomiciliary resting females using knockdown and entry/exit collection methods can be used to answer questions related to resting and endophilic behaviours and to determine the blood source of engorged females (Service 1993, Service \& Townson 2002, Harbison et al. 2006). In Brazil and other malaria-endemic territories in the American continents, studies of alternative anopheline collection methods to human landing catches are still scarce and restricted to a few research groups (Eiras \& Jepson 1991, Rubio-Palis \& Curtis 1992, Rubio-Palis 1996, Rubio-Palis et al. 1999, 2012, Gama et al. 2007, 2013, Missawa et al. 2011, JBP Lima et al., unpublished observations). Our results show that the development of Shannon-type traps with biological/chemical attractants using either whole organisms or molecules derived from the host should be investigated. The most effective attractant is most likely to be a combination of many odour molecules. Human individuals emit many locating signals, the most powerful being odours. Thus, an appropriate blend of human odour molecules in specific ratios is more likely to act as an effective chemical attractant for anthropophilic anophelines (Eiras \& Jepson 1991).

Knowledge obtained from technology and the results of anopheline collection methods may contribute to efforts to control malaria in the tropical and subtropical areas of the planet, where malaria continues to be an important public health challenge.

\section{ACKNOWLEDGEMENTS}

To Ima Aparecida Braga, for logistical support in the collection areas, and to Rafael Maciel-de-Freitas, for valuable comments on the anopheline collection methods classification.

\section{REFERENCES}

Alencar J, de Mello VS, Serra-Freire NM, Silva JS, Morone F, Guimarães AE 2012. Evaluation of mosquito (Diptera: Culicidae) species richness using two sampling methods in the hydroelectric reservoir of Simplício, Minas Gerais, Brazil. Zoolog Sci 29: 218-222.

Anderson RA, Knols BGJ, Koella JC 2000. Plasmodium falciparum sporozoites increase feeding-associated mortality of their mosquito hosts Anopheles gambiae s.l. Parasitology 120: 329-333. 
Ansell J, Hamilton KA, Walraven GEL, Lindsay SW 2002. Shortrange attractiveness of pregnant women to Anopheles gambiae mosquitoes. Trans R Soc Trop Med Hyg 96: 113-116.

Beaty BJ, Marquardt WC 1996. Collecting methods for vector surveillance. In BJ Beaty, WC Marquardt (eds.), The biology of disease vectors, University Press of Colorado, p. 471-491.

Beier JC, Killeen GF, Githure J 1999. Entomologic inoculation rates and Plasmodium falciparum malaria prevalence in Africa. Am J Trop Med Hyg 61: 109-113.

Bell JA, Mickelson NJ, Vaughan JA 2005. West Nile Virus in hostseeking mosquitoes within a residential neighbourhood in Grand Forks, North Dakota. Vector Borne Zoonotic Dis 5: 373-382.

Bernier UR, Kline DL, Barnard DR, Schreck CE, Yost RA 2000. Analysis of human skin emanations by gas chromatography/mass spectrometry. 2. Identification of volatile compounds that are candidate attractants for yellow fever mosquito (Aedes aegypti). Anal Chem 72: 747-756.

Bernier UR, Kline DL, Schreck CE, Yost RA, Barnard DR 2002. Chemical analysis of human skin emanations: comparison of volatiles from humans that differ in attraction of Aedes aegypti (Diptera: Culicidae). J Am Mosq Control Assoc 18: 186-195.

Bhalala HV, Arias JR 2009. The Zumba mosquito trap and BG-Sentinel trap: novel surveillance tools for host-seeking mosquitoes. J Am Mosq Control Assoc 25: 134-139.

Bhalala HV, Smith JD, O'Dea BA, Arias JR 2010. The efficacy of the BG-Sentinel ${ }^{\mathrm{TM}} \mathrm{CO}_{2}$ nozzle in collecting host-seeking mosquitoes in Fairfax County, Virginia. J Am Mosq Control Assoc 26: $226-228$.

Bidlingmayer WJ, Hem DG 1980. The range of visual attraction and the effect of competitive visual attractants upon mosquito (Diptera: Culicidae) flight. Bull Entomol Res 70: 321-342.

Bogh C, Pedersen EM, Mukoko DA, Ouma JH 1998. Permethrin impregnated bed net effects on resting and feeding behaviour of lymphatic filariasis vector mosquitoes in Kenya. Med Vet Entomol 12: 52-59.

Brady J, Costantini C, Sagnon N, Gibson G, Coluzzi M 1997. The role of body odours in the relative attractiveness of different men to malarial vectors in Burkina Faso. Ann Trop Med Parasitol 91 (Suppl. 1): S121-S122.

Braks MA, Anderson RA, Knols BG 1999. Infochemicals in mosquito host selection: human skin microflora and Plasmodium parasites. Parasitol Today 15: 409-413.

Braks MAH, Meijerink J, Takken W 2001. The response of the malaria mosquito, Anopheles gambiae, to two components of human sweat, ammonia and L-lactic acid, in an olfactometer. Physiol Entomol 26: 142-148.

Brioscoe AD, Chittka L 2001. The evolution of color vision in insects. Annu Rev Entomol 46: 471-510.

Brouwer R 1960. Variations in human body odor as a cause of individual differences of attraction for malaria mosquitoes. Trop Geogr Med 12: 186-192.

Brown HE, Paladini M, Cook RA, Kline D, Barnard D, Fish D 2008. Effectiveness of mosquito traps in measuring species abundance and composition. J Med Entomol 45: 517-521.

Burkett DA, Butler JF, Kline DL 1998. Field evaluation of colored light-emitting diodes as attractants for woodland mosquitoes and other Diptera in north central Florida. J Am Mosq Control Assoc 14: 186-195.
Burkett DN, Eubanks DM, Unnasch RT 2008. Preference of female mosquitoes for natural and artificial resting sites. $J$ Am Mosq Control Assoc 24: 228.

Bustamante FM, Pires W 1949. Observações com a armadilha "dawn trap" de Shannon na Baixada Fluminense. Rev Bras Malariol Doencas Trop 2: 153-159.

Cardé RT, Gibson G 2010. Host finding by female mosquitoes: mechanisms of orientation to host odours and other cues. In W Takken, BGJ Knols (eds.), Olfaction in vector-host interactions, Wageningen Academic Publishers, Wageningen, p. 115-142.

Cardé RT, Willis MA 2008. Navigational strategies used by insects to find distant, wind-borne sources of odor. J Chem Ecol 34: 854-866.

Carestia RR, Savage LB 1967. Effectiveness of carbon dioxide as a mosquito attractant in the CDC miniature light trap. Mosq News 27: 90-92.

Carnevale P, Frezil JL, Bosseno MF, Le Pont F, Lancien J 1978. A study of the aggressiveness of Anopheles gambiae in relation to the age and sex of human subjects. Bull World Health Organ 56: 147-154.

Chandler JH, Highton RB, Hill MN 1975. Mosquito of the Kano Plain, Kenya. I. Results of indoor collections in irrigated and noirrigated areas using human baits and light traps. J Med Entomol 12: $504-510$.

Chareonviriyaphap T, Roberts DR, Andre RG, Harlan HJ, Manguin S, Bangs MJ 1997. Pesticide avoidance behavior in Anopheles albimanus, a malaria vector in the Americas. J Am Mosq Control Assoc 13: 171-183.

Chaves LF, Harrington LC, Keogh CL, Nguyen AM, Kitron UD 2010. Blood feeding patterns of mosquitoes: random or structured? Front Zool 7: 3.

Clements AN 1999. The biology of mosquitoes: sensory, reception and behavior, Chapman \& Hall, London, $756 \mathrm{pp}$.

Colless DH 1959. Notes on the culicine mosquitoes of Singapore. VI. Observations on catches made with baited and unbaited trap-nets. Ann Trop Med Parasitol 53: 251-258.

Cooper RD, Frances SP, Popat S, Waterson DG 2004. The effectiveness of light, 1-octen-3-ol and carbon dioxide, as attractants for anopheline mosquitoes in Madang Province, Papua New Guinea. J Am Mosq Control Assoc 20: 239-242.

Cork A 1996. Olfactory basis of host location by mosquitoes and other haematophagous Diptera. Ciba Found Symp 200: 71-88.

Cork A, Park KC 1996. Identification of electrophysiologically-active compounds for the malaria mosquito, Anopheles gambiae, in human sweat extracts. Med Vet Entomol 10: 269-276.

Costantini C 1996. Behavioural studies on West African malaria vectors in the field, PhD Thesis, Imperial College of Science, Technology and Medicine/University of London, London, 228 pp.

Costantini C, Birkett MA, Gibson G, Ziesmann J, Sagnon NF, Mohammed HA, Coluzzi M, Pickett JA 2001. Electroantennogram and behavioural responses of the malaria vector Anopheles gambiae to human-specific sweat components. Med Vet Entomol 15: 259-266.

Costantini C, Gibson G, Sagnon N, della Torre A, Brady J, Coluzzi M 1996. Mosquito responses to carbon dioxide in a West African Sudan savanna village. Med Vet Entomol 10: 220-227.

Costantini C, Sagnon N, della Torre A, Diallo M, Brady J, Gibson G, Coluzzi M 1998a. Odor-mediated host preferences of WestAfrican mosquitoes, with particular reference to malaria vectors. Am J Trop Med Hyg 58: 56-63.

Costantini C, Sagnon N, Sanogo E, Merzagora L, Coluzzi M 1998b. Relationship to human biting collections and influence of light 
and bednet in CDC light-trap catches of West African malaria vectors. Bull Entomol Res 88: 511.

Costantini C, Sagnon NF, della Torre A, Coluzzi M 1999. Mosquito behavioural aspects of vector-human interactions in the Anopheles gambiae complex. Parassitologia 41: 209-217.

Cotton S 2014. 1-octen-3-ol. Available from: chm.bris.ac.uk/motm/ octenol/octenolh.htm.

Curran AM, Rabin SI, Prada PA, Furton KG 2005. Comparison of the volatile organic compounds present in human odor using SPMEGC/MS. J Chem Ecol 31: 1607-1619.

Curtis CF, Lines JD, Ijumba J, Callaghan A, Hill N, Karimzad MA 1987. The relative efficacy of repellents against mosquito vectors of disease. Med Vet Entomol 1: 109-119.

Dao A, Adamou A, Yaro AS, Maïga HM, Kassogue Y, Traoré SF, Lehmann T 2008. Assessment of alternative mating strategies in Anopheles gambiae: does mating occur indoors? J Med Entomol 45: 643-652.

Das SC, Sarkar PK, Das NG 1993. Studies on the evaluation of four traps for collection of mosquitoes in Assam - Arunachal Pradesh bordering areas of India. Ann Med Entomol 2: 5-8.

Davis EE 1984. Development of lactic acid receptor sensitivity and host-seeking behavior in newly emerged female Aedes aegypti mosquitoes. J Insect Physiol 30: 211-215.

Davis JR, Hall T, Chee EM, Majala A, Minjas J, Shiff CJ 1995. Comparison of sampling of anophelines mosquitoes by light trap and human-bait collections indoor in Bagamoyo, Tanzania. Med Vet Entomol 9: 249-255.

de Jong R, Knols BGJ 1995. Selection of biting sites on man by two malaria mosquito species. Experientia 51: 80-84.

Dekker T, Takken W 1998. Differential responses of mosquito sibling species Anopheles arabiensis and An. quadriannulatus to carbon dioxide, a man or a calf. Med Vet Entomol 12: 136-140.

Dennett JA, Vessey NY, Parsons RE 2004. A comparison of seven traps used for collection of Aedes albopictus and Aedes aegypti originating from a large tire repository in Harris County (Houston), Texas. J Am Mosq Control Assoc 20: 342-349.

Diabaté A, Bilgo E, Dabiré RK, Tripet F 2013. Environmentally friendly tool to control mosquito populations without risk of insecticide resistance: the Lehmann's funnel entry trap. Malar J 12: 196.

Diuk-Wasser MA, Toure MB, Dolo G, Bagayoko M, Sogoba N, Traore SF, Manoukis N, Taylor CE 2005. Vector abundance and malaria transmission in rice-growing villages in Mali. Am J Trop Med Hyg 72: 725-731.

Duo-quan W, Lin-hua T, Zhen-cheng G, Xiang Z, Man-ni Y, Weikang J 2012. Comparative evaluation of light-trap catches, electric motor mosquito catches and human biting catches of Anopheles in the three gorges reservoir. PLoS ONE 7: e28988.

Dusfour I, Carinci R, Gaborit J, Issaly J, Girod R 2010. Evaluation of four methods for colleting malaria vectors in French Guiana. J Econ Entomol 103: 973-976.

Dusfour I, Issaly J, Carinci R, Gaborit P, Girod R 2012. Incrimination of Anopheles (Anopheles) intermedius Peryassú, An. (Nyssorhynchus) nuneztovari Gabaldón, An. (Nys.) oswaldoi Peryassú as natural vectors of Plasmodium falciparum in French Guiana. Mem Inst Oswaldo Cruz 107: 429-432.

Dutra AP, Natal D, Tubaki RM, Barata JMS, Menezes RMT, Urbinatti PR, Costa AIP 1996. Mosquitos (Diptera: Culicidae) da Reserva Estadual de Pedro de Toledo (Juquitiba, SP, Brasil). Rev Bras Entomol 40: 375-378.
Edman J, Kittayapong P, Linthicum K, Scott T 1997. Attractant resting boxes for rapid collection and surveillance of Aedes aegypti (L.) inside houses. J Am Mosq Control Assoc 13: 24-27.

Eiras AE 2001. Mediadores químicos entre hospedeiros e insetos vetores de doenças médico-veterinárias. In EF Vilela, TMC Della Lucia (eds.), Feromônios de insetos: biologia, química e emprego no manejo de pragas, Editora Holos, Ribeirão Preto, p. 99-122.

Eiras AE, Jepson PC 1991. Host location by Aedes aegypti (Diptera, Culicidae) - a wind tunnel study of chemical cues. Bull Entomol Res 81: 151-160.

Escovar JE, González R, Quiñones ML 2013. Anthropophilic biting behaviour of Anopheles (Kerteszia) neivai Howard, Dyar \& Knab associated with Fishermen's activities in a malaria-endemic area in the Colombian Pacific. Mem Inst Oswaldo Cruz 108: 1057-1064.

Faran ME, Linthicum KJ 1981. A handbook of the Amazon species of Anopheles (Nyssorhynchus) (Diptera: Culicidae). Mosq System 13: 1-8.

Faye O, Diallo S, Gaye O, Ndir O, Faye O 1992. Comparative efficacy of the use of CDC light traps and humans to sampling Anopheles populations. Results obtained in the area of Bignona (Senegal). Bull Soc Pathol Exot 85: 185-189.

Forattini OP 2002. Culicidologia médica, EDUSP, São Paulo, 860 pp.

Fornadel CM, Norris LC, Norris DE 2010. Centers for Disease Control light traps for monitoring Anopheles arabiensis human biting rates in an area with low vector density and high insecticidetreated bed net use. Am J Trop Med Hyg 83: 838-842.

Gallagher M, Wysocki CJ, Leyden JJ, Spielman AI, Sun X, Preti G 2008. Analyses of volatile organic compounds from human skin. Br J Dermatol 159: 780-791.

Gama RA, Andrade AJ, Andrade MR, Resende MC, Eiras AE 2007. Avaliação da armadilha HP iscada com diferentes taxas de liberação de octenol na captura de anofelinos (Diptera: Culicidae) em Brejo do Mutambal, município de Varzelândia, estado de Minas Gerais. Rev Soc Bras Med Trop 40: 408-410.

Gama RA, da Silva IM, Geier M, Eiras AE 2013. Development of the BG-Malaria trap as an alternative to human-landing catches for the capture of Anopheles darlingi. Mem Inst Oswaldo Cruz 108: 763-771.

Garrett-Jones C 1964. Prognosis for interruption of malaria transmission through assessment of the mosquito's vectorial capacity. $\mathrm{Na}$ ture 204: 1173-1175.

Garrett-Jones C, Magayuka SA 1975. Studies on the natural incidence of Plasmodium and Wuchereria infections in Anopheles in rural East Africa. I - Assessment of densities by trapping hungry female Anopheles gambiae Giles; species A, World Health Organization/Organisation Mondiale de la Santé, Geneva, 18 pp.

Geier M, Bosch OJ, Boeckh J 1999. Ammonia as an attractive component of host odor for the yellow fever mosquito Aedes aegypti. Chem Senses 24: 647-653.

Geier M, Rose A, Eiras AE inventors, University of Regensburg, applicant 2004. Insektenfalle. Worldwide patent WO 04/054358 A2.

Gilbert IH, Gouck HK, Smith N 1966. Attractiveness of men and women to Aedes aegypti and relative protection time obtained with DEET. Fla Entomol 49: 53-66.

Gillies MT 1980. The role of carbon dioxide in host finding by mosquitoes. Bull Entomol Res 70: 525-532.

Gillies MT, de Meillon DB 1968. The Anopheles of Africa south of Sahara (Ethiopian Zoogeographic region), 2nd ed., Vol. 54, South African Institute for Medical Research, Johannesburg, 343 pp. 
Gillies MT, Wilkes TJ 1968. A comparison of the range of attraction of animal baits and of carbon dioxide for some West African mosquitoes. Bull Entomol Res 59: 441-456.

Gillies MT, Wilkes TJ 1970. The range of attraction of single baits for some West African mosquitoes. Bull Entomol Res 60: 225-235.

Githeko AK, Mbogo CN, Curtis CF, Lines J, Lengeler C 1996. Entomological monitoring of large-scale vector-control interventions. Parasitol Today 12: 127-128.

Githeko AK, Service MW, Mbogo CM, Atieli FA, Juma FO 1994. Sampling Anopheles arabiensis, A. gambiae sensu lato and $A$. funestus (Diptera: Culicidae) with CDC light-traps near a rice irrigation area and a sugarcane belt in western Kenya. Bull Entomol Res 84: 319-324.

Govella N, Moore JD, Killeen GF 2010. An exposure-free tool for monitoring adult malaria mosquito populations. Am J Trop Med Hyg 83: 596-600.

Govella NJ, Chaki PP, Geissbuhler Y, Kannady K, Okumu F, Charlwood JD, Anderson RA, Killeen GF 2009. A new tent trap for sampling exophagic and endophagic members of the Anopheles gambiae complex. Malar J 8: 157.

Govella NJ, Chaki PP, Mpangile JM, Killeen GF 2011. Monitoring mosquitoes in urban Dar es Salaam: evaluation of resting boxes, window exit traps, CDC light traps, Ifakara tent traps and human landing catches. Parasit Vectors 4: 40.

Haddow AJ 1942. The mosquito fauna and climate of native huts at Kisumu, Kenya. Bull Entomol Res 33: 91-142.

Hall DR, Beevor PS, Cork A, Nesbitt BF, Vale GA 1984. A potent olfactory stimulant and attractant for tsetse isolated from cattle odours. Int J Trop Insect Sci 5: 335-339.

Hallem EA, Fox AN, Zwiebel LJ, Carlson JR 2004. Olfaction: mosquito receptor for human-sweat odorant. Nature 427: 212-213.

Harbison JE, Mathenge EM, Misiani GO, Mukabana WR, Day JF 2006. A simple method for sampling indoor-resting malaria mosquitoes Anopheles gambiae and Anopheles funestus (Diptera: Culicidae) in Africa. J Med Entomol 43: 473-479.

Harris C, Kihonda J, Lwetoijera D, Dongus S, Devine G, Majambere S 2011. A simple and efficient tool for trapping gravid Anopheles at breeding sites. Parasit Vectors 4: 125.

Hay SI, Rogers DJ, Toomer JF, Snow R 2000. Annual Plasmodium falciparum entomological inoculation rates across Africa: literature survey, internet access and review. Trans $R$ Soc Trop Med Hyg 94: 113-127.

Hazelwood LA, Daran J-M, van Maris AJA, Pronk JT, Dickinson JR 2008. The Ehrlich pathway for fusel alcohol production: a century of research on Saccharomyces cerevisiae metabolism. Appl Environ Microbiol 74: 2259-2266.

Headlee TJ 1928. The development of mechanical apparatus for detecting the presence of mosquitoes in various localities. Proceedings of the New Jersey Mosquito Extermination Association 15: 160-168.

Healy TP, Copland MJ 2000. Human sweat and 2-oxopentanoic acid elicit a landing response from Anopheles gambiae. Med Vet Entomol 14: 195-200.

Healy TP, Copland MJW, Cork A 2002. Landing responses of Anopheles gambiae elicited by oxocarboxylic acids. Med Vet Entomol 16: $126-132$

Healy TP, Copland MWJ 1995. Activation of Anopheles gambiae mosquitoes by carbon-dioxide and human breath. Med Vet Entomol 9: 331336.

Hemingway J, Field L, Vontas J 2002. An overview of insecticide resistance. Science 298: 96-97.
Hii JLK, Smith T, Mai A, Ibam E, Alpers MP 2000. Comparison between anopheline mosquitoes (Diptera: Culicidae) caught using different methods in a malaria endemic area of Papua New Guinea. Bull Entomol Res 90: 211-219.

Himeidan YE, Elbashir MI, Adam I 2004. Attractiveness of pregnant women to the malaria vector, Anopheles arabiensis, in Sudan. Ann Trop Med Parasitol 98: 631-633.

Hiwat H, Andriessen R, de Rijk M, Koenraadt CJM, Takken W 2011a. Carbon dioxide baited trap catches do not correlate with human landing collections of Anopheles aquasalis in Suriname. Mem Inst Oswaldo Cruz 106: 360-364.

Hiwat H, de Rijk M, Andriessen R, Koenraadt CJ, Takken W 2011b. Evaluation of methods for sampling the malaria vector Anopheles darlingi (Diptera, Culicidae) in Suriname and the relation with its biting behavior. J Med Entomol 48: 1039-1046.

Hoel DF, Obenauer PJ, Clark M, Smith R, Hughes TH, Larson RT, Diclaros JW, Allan SA 2011. Efficacy of ovitrap colors and patterns for attracting Aedes albopictus at suburban field sites in northcentral Florida. J Am Mosq Control Assoc 27: 245-251.

Ijumba JN, Mosha FW, Lindsay SW 2002. Malaria transmission risk variations derived from different agricultural practices in an irrigated area of northern Tanzania. Med Vet Entomol 16: 28-38.

Jawara M, Awolola TS, Pinder M, Jeffries D, Smallegange RC, Takken W, Conway DJ 2011. Field testing of different chemical combinations as odor baits for trapping wild mosquitoes in the Gambia. PLoS ONE 6: e19676.

Jawara M, Smallegange RC, Jeffries D, Nwakanma DC, Awolola TS, Knols BGJ, Takken W, Conway DJ 2009. Optimizing odor-baited trap methods for collecting mosquitoes during the malaria season in the Gambia. PLoS ONE 4: e8167.

Johansen CA, Montgomery BL, Mackenzie JS, Ritchie SA 2003. Efficacies of the Mosquito Magnet ${ }^{\mathrm{TM}}$ and counterflow geometry traps in north Queensland, Australia. J Am Mosq Control Assoc 19: 265-270.

Joshi GP, Service MW, Pradhan GD 1975. A survey of species A and $\mathrm{B}$ of the Anopheles gambiae Giles complex in the Kisumu area of Kenya prior to insecticidal spraying with OMS-43 (fenitrothion). Ann Trop Med Parasitol 69: 91-104.

Kaufman PE, Butler JF, Nelson C 2008. Evaluation of the mosquito sentinel 360 trap in Florida residential environments. J Am Mosq Control Assoc 24: 528-533.

Kay BH 1982. Collection of resting adult mosquitoes at Kowanyama, northern Queensland and Charleveville, south west Queensland. Aust J Entomol 22: 19-24.

Kelly-Hope LA, McKenzie FE 2009. The multiplicity of malaria transmission: a review of entomological inoculation rate measurements and methods across sub-Saharan Africa. Malar J 8: 19.

Kilama WL 2010. Health research ethics in malaria vector trials in Africa. Malar $J 9$ (Suppl. 3): S3.

Killeen GF, Tami A, Kihonda J, Okumu FO, Kotas ME, Grundmann H, Kasigudi N, Ngonyani H, Mayagaya V, Nathan R, Abdulla S, Charlwood JD, Smith TA, Lengeler C 2007. Cost-sharing strategies combining targeted public subsidies with private-sector delivery achieve high bednet coverage and reduced malaria transmission in Kilombero valley, southern Tanzania. BMC Infect Dis 7: 121.

Kitau JJ, Pates H, Rwegoshora TR, Rwegoshora D, Matowo J, Kweka EJ, Mosha FW, Mckenzie K, Magesa SM 2010. The effect of Mosquito Magnet liberty plus trap on the human mosquito biting rate under semi-field conditions. J Am Mosq Control Assoc 26: $287-294$. 
Kitau JJ, Rwegoshora RR, Rwegoshora D, Matowo J, Mosha FW, Magesa SM 2009. The effect of combined use of Mosquito Magnet Liberty Plus ${ }^{\mathrm{TM}}$ trap and insecticide treated net on human biting rate of Anopheles gambiae s.s. and Culex quinquefasciatus. Tanzan J Health Res 11: 84-89.

Kline DL 1998. Olfactory responses and field attraction of mosquitoes to volatiles from limburger cheese and human foot odor. $J$ Vector Ecol 23: 186-194.

Kline DL 1999. Comparison of two American biophysics mosquito traps: the professional and a new counterflow geometry trap. J Am Mosq Control Assoc 15: 276-282.

Kline DL 2002. Evaluation of various models of propane-powered mosquito traps. $J$ Vector Ecol 27: 1-7.

Kline DL 2007. Semiochemicals, traps/targets and mass trapping technology for mosquito management. J Am Mosq Control Assoc 23: $241-251$.

Kline DL, Lemire GF 1995. Field evaluation of heat as an added attractant to traps baited with carbon dioxide and octenol for Aedes taeniorhynchus. J Am Mosq Control Assoc 11: 454-456.

Kline DL, Takken W, Wood JR, Carlson DA 1990a. Field studies on the potential of butanone, carbon dioxide, honey extract, 1-octen3-ol, L-lactic acid and phenols as attractants for mosquitoes. Med Vet Entomol 4: 383-391.

Kline DL, Wood JR, Cornell JA 1991. Interactive effects of 1-octen-3 -ol and carbon dioxide on mosquito (Diptera: Culicidae) surveillance and control. J Med Entomol 28: 254-258.

Kline DL, Wood JR, Morris CD 1990b. Evaluation of 1-octen-3-ol as an attractant for Coquillettidia perturbans, Mansonia spp and Culex spp associated with phosphate mining operations. $J$ Am Mosq Control Assoc 6: 605-611.

Knols BGJ 1996. Odor mediated host-seeking behaviour of the Afrotropical malaria vector Anopheles gambiae Giles, PhD Thesis, Wageningen Agricultural University, Wageningen, 213 pp.

Knols BGJ, de Jong R 1996. Limburger cheese as an attractant for the malaria mosquito Anopheles gambiae s.s. Parasitol Today 12: $159-161$.

Knols BGJ, de Jong R, Takken W 1995. Differential attractiveness of isolated humans to mosquitoes in Tanzania. Trans $R$ Soc Trop Med Hyg 89: 604-606.

Knols BGJ, Van Loon JJA, Cork A, Robinson RD, Adam W, Meijerink J, de Jong R, Takken W 1997. Behavioural and electrophysiological responses of the female malaria mosquito Anopheles gambiae Giles (Diptera: Culicidae) towards limburger cheese volatiles. Bull Entomol Res 87: 151-159.

Kulkarni MA, Kweka E, Nyale E, Lyatuu E, Mosha FW, Chandramohan D, Rau ME, Drakeley C 2006. Entomological evaluation of malaria vectors at different altitudes in Hai district, northeastern Tanzania. J Med Entomol 43: 580-588.

Kweka EJ, Mahande AM 2009. Comparative evaluation of four mosquitoes sampling methods in rice irrigation schemes of lower Moshi, northern Tanzania. Malar J 8: 149.

Kweka EJ, Mwang'onde BJ, Kimaro E, Msangi S, Massenga CP, Mahande AM 2009. A resting box for outdoor sampling of adult Anopheles arabiensis in rice irrigation schemes of lower Moshi, northern Tanzania. Malar J 8: 82 .

Kweka EJ, Mwang'onde BJ, Mahande AM 2010. Optimization of odor-baited resting boxes for sampling malaria vector, Anopheles arabiensis Patton, in arid and highland areas of Africa. Parasit Vectors 3: 75.
Laganier R, Randimby FM, Rajaonarivelo V, Robert V 2003. Is the Mbita trap a reliable tool for evaluating the density of anopheline vectors in the highlands of Madagascar? Malar J 2: 42.

Le Goff G, Carnevale P, Fondjo E, Robert V 1997. Comparison of three sampling methods of man-biting anophelines in order to estimate the malaria transmission in a village in south Cameroon. Parasite 4: 75-80.

Le Goff G, Carnevale P, Robert V 1993. Comparison of catches by landings on humans and by CDC light traps for sampling of mosquitoes and evaluation of malaria transmission in south Cameroon. Ann Soc Belg Med Trop 73: 55-60.

Lee HI, Seo BY, Shin EH, Burkett DA, Lee JK, Shin YH 2009. Efficiency evaluation of Nozawa-style black light trap for control of anopheline mosquitoes. Korean J Parasitol 47: 159-165.

Lindsay S, Ansell J, Selman C, Cox V, Hamilton K, Walraven G 2000. Effect of pregnancy on exposure to malaria mosquitoes. Lancet 355: 1972.

Lindsay SW, Adiamah JH, Miller JE, Pleass RJ, Armstrong JRM 1993. Variation in attractiveness of human subjects to malaria mosquitoes (Diptera: Culicidae) in the Gambia. J Med Entomol 30: 308-373.

Lines JD, Curtis CF, Wilkes TJ, Njunwa KJ 1991. Monitoring human biting mosquitoes (Diptera: Culicidae) in Tanzania with lighttraps hung beside mosquito nets. Bull Entomol Res 81: 77-84.

Lourenço-de-Oliveira R 1984. Alguns aspectos da ecologia dos mosquitos (Diptera: Culicidae) de uma área de planície (Granjas Calábria), em Jacarepaguá, Rio de Janeiro. I. Frequência comparativa das espécies em diferentes ambientes e métodos de coleta. Mem Inst Oswaldo Cruz 79: 479-490.

Lourenço-de-Oliveira R, Guimarães AEG, Arlé M, da Silva TF, Castro MG, Motta MA, Deane LM 1989. Anopheline species, some of their habits and relation to malaria in endemic areas of Rondônia state, Amazon Region of Brazil. Mem Inst Oswaldo Cruz 84: 501-514.

Lozovei AL 2001. Culicídeos. In CB Marcondes (ed.), Entomologia médica e veterinária, Atheneu, São Paulo, p. 59-103.

MacDonald G 1957. The epidemiology and control of malaria, Oxford University Press, London, $201 \mathrm{pp}$.

Maciel-de-Freitas R, Eiras AE, Lourenço-de-Oliveira R 2006. Field evaluation of effectiveness of the BG-Sentinel, a new trap for capturing adult Aedes aegypti (Diptera: Culicidae). Mem Inst Oswaldo Cruz 101: 321-325.

Magbity EB, Lines JD 2002. Spatial and temporal distribution of Anopheles gambiae s.l. (Diptera: Culicidae) in two Tanzanian villages: implication for designing mosquito sampling routines. Bull Entomol Res 92: 483-488.

Magbity EB, Lines JD, Marbiah MT, David K, Peterson E 2002. How reliable are light traps in estimating biting rates of adult Anopheles gambiae s.l. (Diptera: Culicidae) in the presence of treated bed nets? Bull Entomol Res 92: 71-76.

Mahande A, Mosha F, Mahande J, Kweka E 2007. Feeding and resting behaviour of malaria vector, Anopheles arabiensis with reference to zooprophylaxis. Malar J 6: 100.

Mahande AM, Mwang'onde BJ, Msangi S, Kimaro E, Mnyone LL, Mazigo HD, Mahande MJ, Kweka EJ 2010. Is aging raw cattle urine efficient for sampling Anopheles arabiensis Patton? BMC Infect Dis 10: 172.

Malaise R 1936. A new insect-trap. Entomol Tidskr 58: 148-160. 
Massad E, Coutinho FAB 2012. Vectorial capacity, basic reproduction number, force of infection and all that: formal notation to complete and adjust their classical concepts and equations. Mem Inst Oswaldo Cruz 107: 564-567.

Mathenge E, Misiani E, Oulo DO, Irungu LW, Ndegwa P, Smith TA, Killeen GF, Knols BGJ 2005. Comparative performance of the Mbitatrap, CDC light trap and the human landing catch in the sampling of Anopheles arabiensis, An. funestus and culicine species in a rice irrigation scheme in western Kenya. Malar J 4: 7.

Mathenge EM, Killeen GF, Oulo DO, Irungu LW, Ndegwa PN, Knols BGJ 2002. Development of an exposure-free bed net trap for sampling Afrotropical malaria vectors. Med Vet Entomol 16: 67-74.

Mathenge EM, Omweri GO, Irungu LW, Ndegwa PN, Walczak E, Smith TA, Killeen GF, Knols BG 2004. Comparative field evaluation of the Mbita trap, the Centers for Disease Control light trap and the human landing catch for sampling of malaria vectors in western Kenya. Am J Trop Med Hyg 70: 33-37.

Mayer MS, James JD 1969. Attraction of Aedes aegypti (L.): responses to human arms, carbon dioxide and air currents in a new type of olfactometer. Bull Entomol Res 58: 629-643.

Mboera LE, Takken W, Sambu EZ 2000a. The response of Culex quinquefasciatus (Diptera: Culicidae) to traps baited with carbon dioxide, 1-octen-3-ol, acetone, butyric acid and human foot odor in Tanzania. Bull Entomol Res 90: 155-159.

Mboera LEG 1999. Chemical ecology of the behaviour of the filariasis mosquito Culex quinquefasciatus Say, $\mathrm{PhD}$ Thesis, Wageningen Agricultural University, Wageningen 189 pp.

Mboera LEG 2005. Sampling techniques for adult Afrotropical malaria vectors and their reliability in the estimation of entomological inoculation rate. Tanzan Health Res Bull 7: 117-124.

Mboera LEG, Kihonda J, Braks MAH, Knols BGJ 1998. Short report: influence of Centers of Disease Control light trap position, relative to a human baited bed net on catches of Anopheles gambiae and Culex quinquefasciatus in Tanzania. Am J Trop Med Hyg 59: 595-596.

Mboera LEG, Knols BGJ, Braks MAH, Takken W 2000b. Comparison of carbon dioxide-baited trapping systems for sampling outdoor mosquito populations in Tanzania. Med Vet Entomol 14: 257-263.

Mboera LEG, Knols BGJ, Takken W, della Torre A 1997. The response of Anopheles gambiae s.l. and A. funestus (Diptera: Culicidae) to tents baited with human odor or carbon dioxide in Tanzania. Bull Entomol Res 87: 173-178.

Mboera LEG, Takken W 1997. Carbon dioxide chemotropism in mosquitoes (Diptera: Culicidae) and its potential in vector surveillance and management programmes. Med Vet Entomol 85: 355-368.

Mbogo CN, Glass GE, Forster D, Kabiru EW, Githure JI, Ouma JH, Beier JC 1993. Evaluation of light traps for sampling anopheline mosquitoes in Kilifi, Kenya. J Am Mosq Control Assoc 9: 260-263.

Meijerink J, Braks MA, Van Loon JJ 2001. Olfactory receptors on the antennae of the malaria mosquito Anopheles gambiae are sensitive to ammonia and other sweat-borne components. $J$ Insect Physiol 47: 455-464.

Mirabello L, Vineis JH, Yanoviak SP, Scarpassa VM, Povoa MM, Padilla N, Achee NL, Conn JE 2008. Microsatellite data suggest significant population structure and differentiation within the malaria vector Anopheles darlingi in Central and South America. BMC Ecol 8: 3.

Missawa NA, Ribeiro ALM, Maciel GBML, Zeilhofer P 2011. Comparação de métodos de captura para o diagnóstico da população de anofelinos adultos do estado de Mato Grosso. Rev Soc Bras Med Trop 4: 555-560.

Mouatcho JC, Hargreaves K, Koekemoer LL, Brooke BD, Oliver SV, Hunt MC 2007. Indoor collections of Anopheles funestus group (Diptera: Culicidae) in sprayed houses in northern KwaZulu - Natal, South Africa. Malar J 6: 30.

Muenworn V, Akaratanakul P, Bangs MJ, Parbaripai A, Chareonviriyaphap T 2006. Insecticide induced behavioral responses in two populations of Anopheles maculatus and Anopheles sawadwongporni malaria vectors in Thailand. J Am Mosq Control Assoc 22: 689-698.

Muirhead-Thomson RC 1951. The distribution of anopheline mosquito bites among different age groups. A new factor in malaria epidemiology. Br Med J 1: 1114-1117.

Muirhead-Thomson RC 1960. The significance of irritability, behaviouristic avoidance and allied phenomena in malaria eradication. Bull World Health Organ 22: 721-734.

Mukabana WR 2002. Differential attractiveness of humans to the African malaria vector Anopheles gambiae Giles: effects of host characteristics and parasite infection, $\mathrm{PhD}$ Thesis, Wageningen University, Wageningen, $146 \mathrm{pp}$.

Mukabana WR, Takken W, Coe R, Knols BGJ 2002. Host-specific cues cause differential attractiveness of Kenyan men to the African malaria vector Anopheles gambiae. Malar J 1: 17.

Mukabana WR, Takken W, Killeen GF, Knols BGJ 2004a. Allomonal effect of breath contributes to differential attractiveness of humans to the African malaria vector Anopheles gambiae. Malar J 3: 1.

Mukabana WR, Takken W, Killeen GF, Knols BGJ 2004b. The role of breath and body odor in the relative attractiveness of humans to Anopheles gambiae. Malar J 3: 1-8.

Murphy MW, Dunton RF, Perich MJ, Rowley WA 2001. Attraction of Anopheles (Diptera: Culicidae) to volatile chemicals in western Kenya. J Med Entomol 38: 242-244.

Newhouse VF, Chamberlain RW, Johnson JG, Sudia WD 1966. Use of dry ice to increase mosquito catches of the CDC miniature light trap. Mosq News 26: 30-35.

Njiru BN, Mukabana WR, Takken W, Knols BGJ 2006. Trapping of the malaria vector Anopheles gambiae with odor-baited MM-X traps in semi-field conditions in western Kenya. Malar J 5: 39.

Obenauer PJ, Abdel-Dayem MS, Stoops CA, Villinski JT, Tageldin R, Fahmy NT, Diclaro JW, Bolay F 2013. Field responses of Anopheles gambiae complex (Diptera: Culicidae) in Liberia using yeastgenerated carbon dioxide and synthetic lure-baited light traps. J Med Entomol 50: 863-870.

Odetoyinbo JA 1969. Preliminary investigation on the use of a lighttrap for sampling malaria vectors in the Gambia. Bull World Health Organ 40: 547-560.

Odiere M, Bayoh MN, Gimnig J, Vulule J, Irungu L, Walker E 2007. Sampling outdoor, resting Anopheles gambiae and other mosquitoes (Diptera: Culicidae) in western Kenya with clay pots. $J$ Med Entomol 44: 14-22.

Okumu FO, Killeen GF, Ogoma S, Biswaro L, Smallegange RC, Mbeyela E, Titus E, Munk C, Ngonyani H, Takken W, Mshinda H, Mukabana WR, Moore SJ 2010a. Development and field evaluation of a synthetic mosquito lure that is more attractive than humans. PLOS ONE 5: e8951.

Okumu FO, Madumla EP, John AN, Lwetoijera DW, Sumaye RD 2010b. Attracting, trapping and killing disease transmitting mosquitoes using odor-baited stations - the Ifakara odor-baited stations. Parasit Vectors 3: 12. 
Oli K, Jeffery J, Vythilingam I 2005. A comparative study of adult mosquito trapping using dry ice and yeast generated carbon dioxide. Trop Biomed 22: 249-251.

Overgaard HJ, Sæbø S, Reddy MR, Reddy VP, Abaga S, Matias A, Slotman MA 2012. Light traps fail to estimate reliable malaria mosquito biting rates on Bioko Island, Equatorial Guinea. $M a-$ lar J 11: 56.

Owino EA 2011. Sampling of An. gambiae s.s. mosquitoes using limburger cheese, heat and moisture as baits in a homemade trap. BMC Res Notes 4: 284.

Pates H, Curtis C 2005. Mosquito behavior and vector control. Ann Rev Entomol 50: 53-70.

Port GR, Boreham PFL, Bryan JH 1980. The relationship of host size to feeding by mosquitoes of the Anopheles gambiae Giles complex (Diptera: Culicidae). Bull Entomol Res 70: 133-144.

Pothikasikorn J, Overgaard H, Ketavan C, Visetson S, Bangs MJ, Chareonviriyaphap T 2007. Behavioural responses of malaria vectors Anopheles minimus complex, to three classes of agrochemicals in Thailand. J Med Entomol 44: 1032-1039.

Pritchard AE, Pratt HD 1944. A comparison of light trap and animal bait trap anopheline mosquito collections in Puerto Rico. II. A list of the mosquitoes of Puerto Rico. Public Health Rep 59: 221-233.

Qiu YT 2005. Sensory and behavioural responses of the malaria mosquito Anopheles gambiae to human odours, PhD Thesis, Wageningen University, Wageningen, 207 pp.

Qiu YT, Smallegange RC, Ter BC, Spitzen J, Van Loon JJ, Jawara M, Milligan P, Galimard AM, Van Beek TA, Knols BG, Takken W 2007. Attractiveness of MM-X traps baited with human or synthetic odor to mosquitoes (Diptera: Culicidae) in The Gambia. J Med Entomol 44: 970-983.

Qiu YT, Smallegange RC, Vanloon JJA, Terbraak CJF, Takken W 2006. Interindividual variation in the attractiveness of human odours to the malaria mosquito Anopheles gambiae s. s. Med Vet Entomol 20: 280-287.

Quinones ML, Lines J, Thomson M, Jawara M, Greenwood BM 1998. Permethrin-treated bednets do not have a "mass-killing effect" on village populations of Anopheles gambiae. Trans R Soc Trop Med Hyg 92: 373-378.

Rachou RG, Lyons G, Moura-Lima M, Kerr JA 1965. Synoptic epidemiological studies of malaria in El Salvador. Am J Trop Med Hyg 14: 1-62.

Reeves WC 1953. Quantitative field studies on a carbon dioxide chemotropism of mosquitoes. Am J Trop Med Hyg 2: 325-331.

Richards SL, Ponnusamy L, Unnasch TR, Hassan HK, Apperson CS 2006. Host feeding patterns of Aedes albopictus (Diptera: Culicidae) in relation to availability of human and domestic animals in suburban landscapes of Central North Carolina. J Med Entomol 43: 543.

Ritchie SA, Pyke AT, Smith GA, Northill JA, Hall RA, Van den Hurk AF, Johansen CA, Montgomery BL, Mackenzie JS 2003. Field evaluation of a sentinel mosquito (Diptera: Culicidae) trap system to detect Japanese encephalitis in remote Australia. $J$ Med Entomol 40: 249-252.

Robert V, MacIntyre K, Keating J, Trape JF, Duchemin JB, Warren M, Beier JC 2003. Malaria transmission in urban sub-Saharan Africa. Am J Trop Med Hyg 68: 169-176.

Rubio-Palis Y 1996. Evaluation of light traps combined with carbon dioxide and 1-octen-3-ol to collect anophelines in Venezuela. J Am Mosq Control Assoc 12: 91-96.

Rubio-Palis Y, Bevilacqua M, Medina DA, Moreno JE, Cárdenas L, Sánchez V, Estrada Y, Anaya W, Martínez A 2013. Malaria entomological risk factors in relation to land cover in the Lower Caura River Basin, Venezuela. Mem Inst Oswaldo Cruz 108: 220-228.
Rubio-Palis Y, Curtis CF 1992. Evaluation of different methods of catching anopheline mosquitoes in western Venezuela. $J \mathrm{Am}$ Mosq Control Assoc 8: 261-267.

Rubio-Palis Y, Guzman H, Magris M 1999. Evaluación de la eficiencia de trampas de luz vs cebo humano para capturar Anopheles darlingi root. Bol Dir Malariol Saneam Ambient 39: 30-32.

Rubio-Palis Y, Moreno JE, Sánchez V, Estrada Y, Anaya W, Bevilacqua M, Cárdenas L, Martínez A, Medina D 2012. Can Mosquito Magnet ${ }^{\mathbb{\circledR}}$ substitute for human-landing catches to sample anopheline populations? Mem Inst Oswaldo Cruz 107: 546-549.

Saitoh Y, Hattori J, Chinone S, Nihei N, Tsuda Y, Kurahashi H, Kobayashi M 2004. Yeast-generated $\mathrm{CO}_{2}$ as a convenient source of carbon dioxide for adult mosquito sampling. J Am Mosq Control Assoc 20: 261-264.

Sanjad N 2003. Da 'abominável profissão de vampiros’: Emílio Goeldi e os mosquitos no Pará (1905). Hist Cienc Saude Manguinhos 10: 85-111.

Santos F, Lima JBP, Braga IA 2000. Comparison of four methods for collecting adult anophelines mosquitoes from malaria endemic area in Rondonia, Brazil. In Mosquito Vector Control and Biology in Latin America. A Tenth Symposium. J Am Mosq Control Assoc 16: 295-312.

Schmied WH, Takken W, Killeen GF, Knols BG, Smallegange RC 2008. Evaluation of two counterflow traps for testing behaviourmediating compounds for the malaria vector Anopheles gambiae s.s. under semi-field conditions in Tanzania. Malar J 7: 230.

Schreck CE, Kline DL, Carlson DA 1990. Mosquito attraction to substances from the skin of different humans. J Am Mosq Control Assoc 6: 406-410.

Service MW 1970. A battery-operated light-trap for sampling mosquito populations. Bull World Health Organ 43: 635-641.

Service MW 1977. A critical review of procedures for sampling populations of adult mosquitoes. Bull Entomol Res 67: 343-382.

Service MW 1993. Mosquito ecology: field sampling methods, 2nd ed., Elsevier Applied Science, London, 988 pp.

Service MW, Townson H 2002. The Anopheles vector. In: DA Warrell, HM Gilles eds. Essential malariology. Arnold, New York, p. $59-84$.

Sexton JD, Hobbs JH, St Jean V, Jacques JR 1986. Comparison of an experimental updraft ultraviolet light trap with the CDC miniature light trap and biting collections in sampling for Anopheles albimanus in Haiti. J Am Mosq Control Assoc 2: 168-173.

Seyoum A, Sikaala CH, Chanda J, Chinula D, Ntamatungiro AJ, Hawela M, Miller JM, Russell TL, Briet OJ, Killeen GF 2012. Human exposure to anopheline mosquitoes occurs primarily indoors, even for users of insecticide-treated nets in Luangwa Valley, south-east Zambia. Parasit Vectors 5: 101.

Shannon R 1939. Methods for collecting and feeding mosquitoes in jungle, yellow fever studies. Am J Trop Med 19: 131-140.

Sharp BL, Ridl FC, Govender D, Kuklinski J, Kleinschmidt I 2007. Malaria vector control by indoor residual insecticide spraying on the tropical island of Bioko, Equatorial Guinea. Malar J 6: 52.

Shiff CJ, Minjas JN, Hall T, Hunt RH, Lyimo S, Davis JR 1995. Malaria infection potential of anopheline mosquitoes sampled by light trapping indoors in coastal Tanzanian villages. Med Vet Entomol 9: 256-262.

Sikulu M, Govella NJ, Ogoma SB, Mpangile J, Kambi SH, Kannady K, Chaki PC, Mukabana WR, Killeen GF 2009. Comparative evaluation of the Ifakara tent trap-B, the standardized resting boxes and the human landing catch for sampling malaria vectors and other mosquitoes in urban Dar es Salaam, Tanzania. Malar J 8: 197. 
Silva IM 2003. Avaliação de componentes sintéticos do odor humano como atraentes para Aedes aegypti (Diptera: Culicidae) em laboratório e campo, PhD Thesis, Universidade Federal de Minas Gerais, Belo Horizonte, 128 pp.

Silveira-Neto S, Nakano O, Barbin D, Nova NAV 1976. Manual de ecologia dos insetos, Agronômica Ceres, São Paulo, 419 pp.

Silver JB, Service MW 2008. Mosquito ecology: field sampling meth$o d s$, 3rd ed., Springer, London, 1494 pp.

Siphiprasasna R, Jaichapor B, Chanaimongkol S, Khongtak P, Lealsirivattanakul T, Tiang-Trong S, Burkett DA, Perich MJ, Wirtz RA, Coleman RE 2004. Evaluation of candidate traps as tools for conducting surveillance for Anopheles mosquitoes in a malariaendemic area in western Thailand. J Med Entomol 41: 151-157.

Smallegange RC, Qiu YT, Bukovinszkine-Kiss G, Van Loon JJ, Takken W 2009. The effect of aliphatic carboxylic acids on olfactionbased host-seeking of the malaria mosquito Anopheles gambiae sensu stricto. J Chem Ecol 35: 933-943.

Smallegange RC, Qiu YT, Van Loon JJ, Takken W 2005. Synergism between ammonia, lactic acid and carboxylic acids as kairomones in the host-seeking behaviour of the malaria mosquito Anopheles gambiae sensu stricto (Diptera: Culicidae). Chem Senses 30: 145-152.

Smallegange RC, Schmied WH, van Roey KJ, Verhulst NO, Spitzen J, Mukabana WR, Takken W 2010. Sugar-fermenting yeast as an organic source of carbon dioxide to attract the malaria mosquito Anopheles gambiae. Malar J 9: 292.

Smart MR, Brown AWA 1957. Studies on the responses of the female Aedes mosquito. Part VII. The effect of skin temperature, hue and moisture on the attractiveness of the human hand. Bull Entomol Res 47: 89-101.

Smith A 1956. The attractiveness of an adult and child to Anopheles gambiae. East Afr Med J 33: 409-410.

Smith A 1961. Resting habits of Anopheles gambiae and Anopheles pharoensis in salt bush and in crevices in the ground. Nature 190: 1220-1221.

Smith GE, Breeland SG, Packard E 1965. The Malaise trap, a survey tool in medical entomology. Mosq News 25: 398-400.

Snow WF 1970. The effect of a reduction in expired carbon dioxide on the attractiveness of human subjects to mosquitoes. Bull Entomol Res 60: 43-48.

Spencer M 1967. Anopheline attack on mother and infant pairs, Fergusson Island. Papua New Guin Med J 10: 75.

Stoddart DM 1990. The scented ape: the biology and culture of human odour, Cambridge University Press, New York, 286 pp.

Stoops CA, Gionar YR, Rusmiarto S, Susapto D, Andris H, Elyazar IRF, Barbara KA, Munif A 2010. Laboratory and field testing of bednet traps for mosquito (Diptera: Culicidae) sampling in west Java, Indonesia. J Vector Ecol 35: 187-196.

Sudia WD, Chamberlain RW 1962. Battery operated light trap, an improved model. Mosq News 22: 126-129.

Sumodan PK, Kumar A, Yadav RS 2004. Resting behaviour and incrimination of Anopheles stephensi in Goa, India. J Am Mosq Control Assoc 20: 317-318.

Takken W, Dekker T, Wijnholds YG 1997. Odor-mediated behavior of Anopheles gambiae s.s. Giles and An. stephensi Liston in response to $\mathrm{CO}_{2}$, acetone and 1-octen-3-ol. J Insect Behav 10: 395-407.
Takken W, Kline DL 1989. Carbon dioxide and 1-octen-3-ol as mosquito atractants. J Am Mosq Control Assoc 5: 311-316.

Takken W, Knols BGJ 1999. Odor mediated behaviour of Afrotropical malaria mosquitoes. Annu Rev Entomol 44: 131-157.

Taylor B 1975. Changes in the feeding behaviour of a malaria vector, Anopheles farauti Lav., following use of DDT as a residual spray in houses in the British Solomon Islands Protectorate. Trans $R$ Ent Soc Lond 127: 277-292.

Van Thiel PH, Reuter J, Sautet J, Bevere L 1939. On zoophilism and anthropophilism of Anopheles biotypes and species. Riv Malariol 18: 95-124.

Verhulst N, Beijleveld H, Knols B, Takken W, Schraa G, Bouwmeester H, Smallegange R 2009. Cultured skin microbiota attracts malaria mosquitoes. Malar $J$ 8: 302 .

Verhulst NO, Qiu YT, Beijleveld H, Maliepaard C, Knights D, Schulz S, Berg-Lyons D, Lauber CL, Verduijn W, Haasnoot GW, Mumm R, Bouwmeester HJ, Claas FH, Dicke M, Van Loon JJ, Takken W, Knight R, Smallegange RC 2011. Composition of human skin microbiota affects attractiveness to malaria mosquitoes. PLoS ONE 6: e9546.

Vythilingam I, Lian CG, Thim CS 1992. Evaluation of carbon dioxide and 1-octen-3-ol as mosquito attractants. Southeast Asian J Trop Med Public Health 23: 328-331.

Wallace HG, Rudnick A, Rajagopal V 1977. Activity of Tembusu and Umbre viruses in a Malaysian community: mosquito studies. Mosq News 37: 35-42.

Wayne JC 1989. Resting boxes as mosquito surveillance tools. Proceedings of the 82th Annual Meeting of the New Jersey Mosquito Control Association, 7-10 March 1995, Atlantic City, NJ, New Jersey Mosquito Control Association Inc, New Brunswick, p. 53-57.

WHO - World Health Organization 1975a. Manual on practical entomology in malaria. Part I - Vector bionomics and organization of anti-malaria activities, WHO, Geneva, 169 pp.

WHO - World Health Organization 1975b. Manual on practical entomology in malaria. Part II - Methods and techniques, WHO, Geneva, 197 pp.

WHO - World Health Organization 2002. Malaria entomology and vector control - Learner's Guide, WHO, Geneva, 107 pp.

WHO - World Health Organization 2005. World malaria report 2005. Available from: who.int/malaria/publications/atoz/9241593199/en/.

Wilton DP 1975. Mosquito collections in El Salvador with ultraviolet and CDC miniature light traps with and without dry ice. Mosq News 35: 522-525.

Wong J, Bayoh N, Olang G, Killeen GF, Hamel MJ, Vulule JM, Gimnig JE 2013. Standardizing operational vector sampling techniques for measuring malaria transmission intensity: evaluation of six mosquito collection methods in western Kenya. Malar J 12: 143.

Xue RD, Doyle MA, Kline DL 2008. Field evaluation of CDC and Mosquito Magnet $\mathrm{X}$ traps baited with dry ice, $\mathrm{CO}_{2}$ sachet and octenol against mosquitoes. J Am Mosq Control Assoc 24: 249-252.

Zaim M, Ershadi MR, Manouchehri AV, Hamdi MR 1986. The use of $\mathrm{CDC}$ light traps and other procedures for sampling malaria vectors in southern Iran. J Am Mosq Control Assoc 2: 511-515. 